\title{
ПАЛИНОСТРАТИГРАФИЯ И ПАЛЕООБСТАНОВКИ В РАЗРЕЗЕ ГОРОДИЩИ (СРЕДНЕЕ ПОВОЛЖЬЕ, КИМЕРИДЖ-ГОТЕРИВ)
}

Пещевицкая Е. Б.

\begin{abstract}
Аннотация
На основе анализа биостратиграфических последовательностей морских и наземных палиноморф в кимеридже, волжском ярусе и готериве разреза Городище описано 8 палиностратонов по диноцистам и 3 палиностратона по спорам и пыльце. Уточнена альгологическая характеристика и дополнены критерии границ для диноцистовых зон, установленных более ранними исследованиями. Для средней части волжского интервала предложено более детальное расчленение. Впервые установлены слои с диноцистами в готериве и биостратиграфическая последовательность спорово-пыльцевых биостратонов для всего разреза. Показано, что границы большинства палиностратонов имеют значительный корреляционный потенциал. На основе биофациального анализа микрофитопланктона изучена динамика трансгрессивно-регрессивных событий, а также изменения сопутствующих кислородных и трофических условий. Рассматриваются возможные связи обстановок в морском палеобассейне с климатическими изменениями на континенте, которые восстанавливаются по спорово-пыльцевым данным.
\end{abstract}

\section{Ключевые слова:}

Диноцисты, споры и пыльца, кимеридж-готерив, биостратиграфия, корреляция, палеообстановки, европейская часть России. 


\title{
ПАЛИНОСТРАТИГРАФИЯ И ПАЛЕООБСТАНОВКИ В РАЗРЕЗЕ ГОРОДИЩИ (СРЕДНЕЕ ПОВОЛЖЬЕ, КИМЕРИДЖ-ГОТЕРИВ)
}

\author{
Е.Б. Пещевицкая \\ Институт нефтегазовой геологии и геофизики им. А.А. Трофимука СО РАН, 630090, Новосибирск, просп. \\ ак. Коптюга, 3, Россия; PeschevickayaEB@ipgg.sbras.ru
}

На основе анализа биостратиграфических последовательностей морских и наземных палиноморф в кимеридже, волжском ярусе и готериве разреза Городище описано 8 палиностратонов по диноцистам и 3 палиностратона по спорам и пыльце. Уточнена альгологическая характеристика и дополнены критерии границ для диноцистовых зон, установленных более ранними исследованиями. Для средней части волжского интервала предложено более детальное расчленение. Впервые установлены слои с диноцистами в готериве и биостратиграфическая последовательность спорово-пыльцевых биостратонов для всего разреза. Показано, что границы большинства палиностратонов имеют значительный корреляционный потенциал. На основе биофациального анализа микрофитопланктона изучена динамика трансгрессивно-регрессивных событий, а также изменения сопутствующих кислородных и трофических условий. Рассматриваются возможные связи обстановок в морском палеобассейне с климатическими изменениями на континенте, которые восстанавливаются по спорово-пыльцевым данным.

Диноцисты, споры и пыльца, кимеридж-готерив, биостратиграфия, корреляция, палеообстановки, европейская часть России.

\section{ВВЕДЕНИЕ}

Разрез Городищи является одним из наиболее изученных для терминального интервала юры на территории Восточно-Европейской платформы и рассматривается как лектостратотип волжского яруса [Силаков, 1984]. Он расположен на правом берегу р. Волга, в 25 км севернее г. Ульяновск (рис. 1). Разрез неоднократно детально описывался, включая его нижнемеловую часть. Одновременно с этим всесторонне изучались разнообразные макро- и микрофоссилии, что позволило провести детальное биостратиграфическое расчленение по нескольким группам фауны и корреляцию с одновозрастными зональными последовательностями северных и центральных областей Западной Европы [Михайлов, 1966; Герасимов, Михайлов, 1966; Даин, Кузнецова, 1976; Силаков, 1984; Lord et al., 1987; Hantzpergue et al, 1998; Vishnevskaya et al., 1999; Вишневская, Барабошкин, 2001; Захаров, Рогов, 2002; Kessels et al., 2003; Scherzirger, Mitta, 2006; Rogov, 2010 и др.]. Реконструкции палеообстановок основаны на комплексных исследованиях, включающих результаты как палеонтологических, так и непалеонтологических методов [Hantzpergue et al., 1998; Riboulleau, 2000; Ruffell et al., 2002; Colpaert et al., 2018 и др.].

Первоначальная информация о фитопланктоне из разреза Городищи была приведена в работе Lord et al. [1987]. Наиболее полно диноцисты из юрской части разреза были изучены В.И. Ильиной, которая предложила зональную последовательность и 
сопоставила ее с западноевропейской [Riding et al., 1999]. Из волжского яруса были описаны новые виды диноцист [Smith, Harding, 2004]. Позднее были внесены незначительные дополнения в последовательность диноцистовых зон в верхневолжской части разреза [Harding et a., 2011]. Для готерива приводилась только краткая характеристика состава морских и наземных палиноморф [Селькова, Ветошкина, 2012].

Новое палинологическое изучение разреза Городищи направлено на уточнение и более полное палеонтологическое обоснование последовательности диноцистовых зон и выявление надежных корреляционных реперов, а также на реконструкцию палеообстановок. Впервые проведен детальный биостратиграфический анализ споровопыльцевых комплексов.

\section{КРАТКИЕ СВЕДЕНИЯ О РАЗРЕЗЕ ГОРОДИЩИ}

Разрез Городищи сложен терригенными отложениями морского генезиса (рис. 2). Стратиграфический объем разреза определяется, в первую очередь, находками аммонитов. Нижняя часть разреза (5-9 м), сложенная серыми известковистыми глинами, относится большинством исследователей к верхнему кимериджу и по стратиграфическому объему соответствует зонам eudoxus-autissiodorensis севера Западной Европы и pseudomutabilisbeckeri южных и центральных областей этого региона [Герасимов, Михайлов, 1966; Даин, Кузнецова, 1976; Силаков, 1984; Scherzirger, Mitta, 2006 и др.]. По некоторым данным верхний кимеридж имеет в разрезе Городищи бо́льшую мощность (14-17.5 м) [Rogov, 2010 и др.]. Также имеются предположения, что нижнюю часть этого интервала следует относить к нижнему кимериджу (зона суmodoce) [Вишневская, Барабошкин, 2001 и др.]. Различия в мощностях и стратиграфическом объеме этого интервала разреза, вероятно, связаны как с разной степенью обнаженности в различные сезоны, так и с латеральными изменениями. Небольшие вариации в мощности зон по латерали (обычно 1-3 м) отмечаются и для волжского интервала, представленного в нижней части серыми и темносерыми известковистыми глинами, а в верхней - светло-серыми известковистыми песчаниками, часто с зеленоватым, бурым и желтоватым оттенком в следствие значительного содержания глауконита и ожелезнения [Герасимов, Михайлов, 1966; Даин, Кузнецова, 1976; Силаков, 1984; Вишневская, Барабошкин, 2001 и др.]. В целом, зональная последовательность волжского яруса в разрезе понимается более однозначно, хотя ее сопоставление с Западной Европой осложняется постепенно увеличивающимся эндемизмом фауны, особенно в верхней части интервала, что приводит к созданию различных корреляционных моделей [Герасимов, Михайлов, 1966; Hantzpergue et al., 1998; Ruffell et al., 2002; Rogov, 2010 и др.]. В верхней части песчанистого интервала присутствуют перерывы, разрез часто имеет линзовидное строение, что, видимо, приводит к латеральной изменчивости: отмечается выпадение некоторых зон верхневолжского подъяруса или их частей [Герасимов, Михайлов, 1966; Даин, Кузнецова, 1976; Вишневская, Барабошкин, 2001; Опорные разрезы..., 2010 и др.]. Имеются также данные, что в терминальной части этого интервала местами присутствуют рязанский ярус и валанжин [Герасимов, Михайлов, 
1966; Силаков, 1984; Опорные разрезы..., 2010]. Разрез завершается пачкой (1-20 м) темносерых готеривских глин. Находки аммонитов позволяют относить эти отложения к зоне versicolor [Герасимов, Михайлов, 1966; Силаков, 1984; Вишневская, Барабошкин, 2001; Опорные разрезы..., 2010 и др.].

\section{МАТЕРИАЛЫ И МЕТОДЫ}

Палинологическим методом изучено 35 образцов, отобранных в 2010 г. в ходе полевых работ под руководством В.В. Митта (ПИН РАН). Лабораторная обработка образцов включала их дезинтеграцию, растворение в плавиковой кислоте с последующей отмывкой и цетрифугированием в тяжелой кадмиевой жидкости (CdI+KI) с удельным весом 2.25. Для определения процентного соотношения палиноморф наземного и морского генезиса в каждом образце насчитывалось минимум 200 зерен. Затем количество зерен в этих группах также досчитывалось до 200 и содержание таксонов в них определялось отдельно. Для определения границ палиностратонов использовались появление/исчезновение и расцвет ключевых таксонов, которые прослеживаются на определенных стратиграфических рубежах на территории Восточно-Европейской платформы и в других областях Европы, а также в Сибири и Северной Америке.

\section{БИОСТРАТИГРАФИЧЕСКОЕ РАСЧЛЕНЕНИЕ РАЗРЕЗА ПО ДИНОЦИСТАМ}

Изучение нового альгологического материала из кимериджа, волжского яруса и готерива позволило установить в разрезе Городищи 8 биостратонов в ранге зон, подзон и слоев с диноцистами. Распределение диноцист по разрезу приведено на рис. 2. В верхнем кимеридже и нижней части волжского яруса выявлены зоны, ранее установленные В.И. Ильиной [Riding et al., 1999], а верхней части волжского яруса - также и И. Хардингом с соавторами [Harding et al., 2011]. В данной работе они рассматриваются автором как зоны комплексного обоснования, в отличие от прежних работ, где они определялись как биозоны или интервал-зоны. Такой подход вместе с использованием новых материалов позволил привести более полную альгологическую характеристику для этих интервалов, а также уточнить и дополнить палинологические критерии границ зональных подразделений (табл. 1).

Зона Gonyaulacysta jurassica subsp. jurassica была установлена В.И. Ильиной на территории Восточно-Европейской платформы по материалам из разрезов Унжа, Макарьев, Ижма и Городищи [Riding et al., 1999]. По стратиграфическому объему она охватывает практически весь кимеридж. В разрезе Городищи обнажается только ее верхняя часть (рис. 2). Верхняя граница зоны проводилась В.И. Ильиной по исчезновению Gonyaulacysta jurassica subsp. jurassica (Deflandre) Norris et Sarjeant и появлению Corculodinium inaffectum (Drugg) Courtinat. Следует отметить, что на севере Западной Европы и в Сибири C. inaffectum появляется в середине кимериджа (аммонитовые зоны mutabilis и kitchini), а во Франции - с верхней части оксфорда (зона bimammatum) [Courtinat, 1989; Powell, 1992; Никитенко и др., 2015]. Таким образом, появление этого 
вида в верхней части кимериджа в разрезе Городищи (рис. 2) вряд ли можно рассматривать как важный стратиграфический репер. Вид G. jurassica subsp. jurassica встречается редко в верхнем кимеридже Восточно-Европейской платформы [Riding et al., 1999; см. рис. 2]. Анализ литературных данных и материалов автора показывает, что этот вид может встречаться и в более высоких горизонтах: в средней и верхней частях волжского яруса на севере Западной Европы [Heilmann-Clausen, 1987; Poulsen, Riding, 2003], в середине бореального берриаса на севере Сибири [Пещевицкая, 2010], в нижнем валанжине Норвегии [Koevoets et al., 2018]. Таким образом, его исчезновение не является надежным критерием для определения позднекимериджского возраста отложений. Изучение нового материала позволило дополнительно установить в разрезе Городищи присутствие видов Cribroperidinium angulosum (Gitmez) Poulsen, C. ehrenbergii (Gitmez et Sarjeant) Helenes, C.? "cauda" (Gitmez et Sarjeant) Helenes, C.? "systremmatos" (Gitmez et Sarjeant) Stover et Evitt (рис. 2; талб. 1), характерных для кимериджа Англии и Франции [Gitmez, Sarjeant, 1972]. Появление C.? edwardsii (Cookson et Eisenack) Davey в основании следующей зоны дает возможность провести корреляцию с верхним кимериджем Сибири (разрез Нордвик), где зафиксированы наиболее древние находки этого вида [Никитенко и др., 2015]. Интересно отметить появление в верхней части кимериджа Exochosphaeridium phragmites Davey et al., что можно считать наиболее древними находками этого вида, поскольку его постоянное присутствие характерно для берриаса-готерива Западной Европы [Davey, 1982; Leereveld, 1997].

Название следующей зоны, Subtilisphaera? inaffecta, установленной ранее по материалам из разреза Городищи [Riding et al., 1999], изменено в соответствии с пересмотром систематического положения вида-индекса [Courtinat, 2000]. Для обоснования границы с нижележащей зоной кроме перечисленных выше критериев важно появление Cometodinium whitei (Deflandre et Courteville) Stover et Evitt, поскольку это также наблюдается в переходных кимеридж-титонских слоях северной Атлантики и в нижнем титоне Багамского бассейна [Habib, Drugg, 1983; Zotto et al., 1987]. На севере Сибири этот вид появляется несколько выше, в верхней части нижневолжского подъяруса [Никитенко и др., 2015]. Верхняя граница зоны С.? inaffectum проводилась по исчезновению вида-индекса. Однако изучение новых материалов показало, что он исчезает выше, в средневолжском подъярусе (рис. 2). На шельфе Северного моря он изредка присутствует в рязанском ярусе [Heilmann-Clausen, 1987]. Однако следует отметить, что постоянные находки этого вида прекращаются в разрезе Городищи в средней части нижневолжского подъяруса и примерно на этом же стратиграфическом уровне в Западной Европе [Powell, 1992; Poulsen, Riding, 2003].

Вышележащая зона Glossodinium dimorphum была ранее установлена В.И. Ильиной в разрезах Городищи и Кашпир в нижне- и средневолжском подъярусах (аммонитовые зоны sokolovi-panderi) [Riding et al., 1999]. Верхняя граница проводилась по исчезновению вида-индекса, формально совмещаясь с кровлей аммонитовой зоны panderi: в ее верхней части находки этого вида отсутствовали, что подтверждено новыми исследованиями (рис. 
2). В разрезе Кашпир G. dimorphum Ioannides et al. В.И. Ильиной не был обнаружен [Riding et al., 1999], но его присутствие в зоне panderi было зафиксировано более поздними палинологическими исследованиями [Harding et al., 2011]. Однако общий стратиграфический диапазон распространения этого вида шире: на севере Западной Европы он исчезает в середине портланда, в кровле аммонитовой зоны anguiformis [Poulsen, Riding, 2003], что примерно соответствует средней/верхней частям аммонитовой зоны nikitini [Riding et al., 1999; Ruffell et al., 2002 и др.].

Новые палинологические материалы выявили присутствие дополнительных ключевых таксонов в данном интервале, что позволило предложить его более детальное расчленение, выделив в верхней части слои с Muderongia simplex (рис. 2; табл. 1). Ранг этого биостратиграфического подразделения определяется тем, что его нижняя граница не прослежена, поскольку в интервале аммонитовых зон sokolovi и pseudoscythica изучение диноцист автором не проводилось. Появление вида $M$. simplex Alberti можно рассматривать как важный стратиграфический признак. На севере Западной Европы его редкие находки отмечаются с середины верхнего кимериджа sensu anglico (аммонитовая зона pectinatus), но постоянное присутствие наблюдается с зоны pallasioides [Poulsen, Riding, 2003], что примерно соответствует уровню его появления в разрезе Городищи. В Западной Сибири этот вид также появляется в средневолжском подъярусе, но несколько выше, в слоях с Crendonites spp. [Ilyina et al., 2005]. Как важный биостратиграфический признак можно также рассматривать исчезновение вида Cribroperidinium crassinervum (Deflandre) Nohr-Hansen, который характерен для кимериджа северных областей Западной Европы [Nohr-Hansen, 1986]. Наиболее молодые находки этого вида отмечаются на уровне аммонитовой зоны pallasioides, что соответствует уровню его исчезновения в разрезе Городищи. Интересно также отметить присутствие Meiourogonyaulax bejui Zotto et al. в основании слоев с M. simplex, поскольку этот вид исчезает примерно на том же стратиграфическом уровне в Западной Европе: в основании среднего титона в Болгарии [Dodekova, 1994] и середине верхнего кимериджа (основание зоны pectinatus) в Дании [Poulsen, 1996].

Выше по разрезу Городищи автором выделяются слои с Achomosphaera neptuni, Cribroperidinium hansenii. В их основании появляется несколько ключевых видов. C. hansenii Poulsen появляется на территории Дании на очень близком стратиграфическом уровне (аммонитовая зона albani) [Poulsen, 1996]. Наиболее древние находки А. перtuni (Eisenack) Davey et Williams обнаружены на территории Северного моря в средневолжском подъярусе [Heilmann-Clausen, 1987]. Виды Stiphrosphaeridium dictyophorum (Cookson et Eisenack) Lentin et Williams и $S$. anthophorum (Cookson et Eisenack) Lentin et Williams появляются в этой области несколько выше, в переходных средне-верхневолжских слоях [Dybkjaer, 1998]. В разрезе Городищи обнаружены также наиболее древние находки видов Dingodinium spinosum (Duxbury) Davey и Kleithriasphaeridium corrugatum Davey. Вид D. spinosum рассматривается как важный биостратиграфический маркер на севере Западной Европы, но появляется там выше (аммонитовая зона okusensis), что примерно 
соответствует средней части средневолжского подъяруса [Poulsen, Riding, 2003]. На этом же уровне фиксируются наиболее древние находки K. corrugatum [Powell, 1992]. В средней части слоев с А. neptuni, С. hansenii появляется Cassiculasphaeridia sp. sensu Zotto et al., 1987. Этот морфотип характерен для кимериджа и титона Западной Европы [Zotto et al., 1987; Dodekova, 1994]. Однако на севере Сибири он, как и в разрезе Городищи, появляется в средневолжском подъярусе [Никитенко и др., 2015]. В разрезе Городищи интересно также отметить исчезновение Occisucysta balios Gitmez почти в кровле аммонитовой зоны panderi, так как на севере Западной Европы наиболее молодые находки этого вида отмечаются практически на том же уровне - аммонитовые зоны fittoni-albani [Poulsen, 1996; Poulsen, Riding, 2003]. Начиная с верхней части зоны panderi, в разрезе Городищи присутствует Oligosphaeridium patulum Riding et Thomas. На севере Западной Европы этот вид отмечается значительно ниже, с кимериджа (аммонитовая зона cymodoce) [Powell, 1992], но в Сибири фиксируется тоже с нижней части средневолжского подъяруса [Ilyina et al., 2005].

Зона Gochteodinia villosa является важным стратиграфическим и корреляционным репером на севере Западной Европы [Davey, 1982; Powel, 1992; Poulsen, Riding, 2003 и др.]. В разрезе Городищи она была впервые установлена В.И. Ильиной [Riding et al., 1999]. Нижняя граница проводилась на уровне основания аммонитовой зоны fulgens по появлению вида-индекса и исчезновению Prolixosphaeridium parvispinum (Deflandre) Davey et al. Однако анализ литературных данных показывает, что P. parvispinum имеет широкое стратиграфическое распространение и часто встречается как в юрских (начиная с келловея), так и в меловых (по маастрихт включительно) отложениях [Davey, 1979; Herngreen et al., 1986; Powel, 1992; Poulsen, 1996 и др.]. Последующие палинологические исследования показали, что вид G. villosa (Vozzhennikova) Norris в разрезе Городищи появляется ниже, в интервале аммонитовой зоны nikitini [Harding et al., 2011], что также подтверждается материалами автора. В результате, нижняя граница зоны G. villosa смещена вниз по сравнению с первоначальным вариантом и обоснована дополнительными палинологическими критериями: здесь появляется несколько коррелятивных видов (рис. 2). Наиболее древние находки Spiniferites ramosus (Ehrenberg) Mantell обнаружены в переходных средне-верхневолжских слоях на шельфе Северного моря [Heilmann-Clausen, 1987] и в средней части портланда в Нидерландах (аммонитовая зона kerberus) [Herngreen et al., 2000], что примерно соответствует уровню появления этого вида в разрезе Городищи. В Болгарии в основании верхнего титона появляется другой вид этого рода, $S$. alatus Duxbury [Dodekova, 1994]. В разрезе Городищи интересно также отметить исчезновение Epiplosphaera reticulospinosa Klement в нижней части аммонитовой зоны fulgens. В целом, в Западной Европе этот вид характерен для оксфорда-кимериджа [Sarjeant, 1979; Kunz, 1990], но прослеживается до кровли среднего титона по материалам из Болгарии [Dodekova, 1994]. В нижней части зоны fulgens в разрезе Городищи исчезают также виды Oligosphaeridium patulum и Tubotuberella “dentata” Rynaud. Первый вид позволяет проводить корреляцию с Сибирью, где его распространение ограничено кровлей 
средневолжского подъяруса [Ilyina et al., 2005]. На севере Западной Европы он исчезает ниже, в нижней части портланда (аммонитовая зона albani) [Partington et al., 1993]. Вид T. “dentata” характерен для более низких горизонтов юры и рассматривается как ключевой таксон верхнего келловея и низов оксфорда на севере Западной Европы [Riding, 2012]. Однако во Франции этот вид зафиксирован в средней части титона [Schnyder et al., 2012]. В разрезе Городищи он исчезает в верхневолжском подъярусе, что позволяет рассматривать эти находки как наиболее молодые. Интересно отметить находку вида Cordosphaeridium inodes (Klumpp) Eisenack, который характерен для верхнего мела и палеогена [Powell, 1992; Stoian, 2002]. Экземпляр из разреза Городищи отличается от типового материала только меньшим размером.

На нижнюю часть нижнего мела в разрезе Городищи приходится стратиграфический перерыв (рис. 2). В готериве установлены слои с Aptea anaphrissa, Gardodinium trabeculosum. Количественный пик G. trabeculosum (Gocht) Alberti наблюдается в нижней части палиностратона, что также характерно для готерива на Приполярном Урале [Лебедева, Никитенко, 1998]. Так же, как и в разрезе Городищи, повышенное количество $G$. trabeculosum там наблюдается непостоянно. На севере Западной Европы акме этого вида рассматривается как важный биостратиграфический и корреляционный признак. Одноименная подзона установлена здесь также в средней части готерива, в интервале аммонитовых зон regale-gottschei [Davey, 1979; Rawson, Riley, 1982].

Важной стратиграфической чертой готеривского комплекса диноцист в разрезе Городищи является присутствие Aptea anaphrissa (Sarjeant) Sarjeant et Stover, хотя ряд исследователей рассматривает его как характерный барремский вид. Акме-зона А. anaphrissa установлена в барреме Восточной Канады и на о. Ньюфаундленд по количественному пику вида-индекса [Jenkins et al., 1974; Bujak, Williams, 1978]. Однако в Гренландии, на юге Англии и шельфе Северного моря количественный пик этого вида наблюдается только в средней части баррема, где выделяется подзона А. anaphrissa в составе зон Sirmiodinium grossii [Rawson, Riley, 1982], Odontochitina operculata [NohrHansen, 1993] и Batioladinium longicornutum [Harding, 1986]. В этих работах появление А. anaphrissa отмечается с основания баррема. Тем не менее, анализ литературы и материалов автора по Сибири показывает, что диапазон стратиграфического распространения этого вида шире. В Сибири A. anaphrissa появляется в средней части готерива, в интервале, соответствующем аммонитовой зоне versicolor [Пещевицкая, 2010; Никитенко и др., 2013]. В том же стратиграфическом интервале этот морфотип отмечен на Приполярном Урале [Лебедева, Никитенко, 1998] Присутствие A. anaphrissa в средней части готерива отмечается также в Норвегии [Aarhus et al., 1986], Дании [HeilmannClausen, 1987] и Арктической Канаде [Pocock, 1976]. На территории Баренцевоморского шельфа значительное количество этого вида наблюдалось также в середине готерива, в интервале, соответствующем аммонитовым зонам regale-inversum [Smelror et al., 1998]. Следует отметить, что в тетических областях A. anaphrissa отмечается ниже: с основания готерива на территории Франции [Fauconnier, 1982] и с верхов валанжина на 
западноафриканском шельфе Атлантики [Williams, Bujak, 1980]. Различия в представлениях о стратиграфическом распространении вида могут быть связаны с разным пониманием его морфологического объема. Некоторые исследователи полагали, что морфология вида A. anaphrissa сближает его с представителями семейства Areoligeraceae, и рассматривали вид в составе рода Теnua [Benedek, 1972; Pocock, 1976]. Именно такие морфотипы встречаются в валанжине и готериве [Fauconnier, 1982; Лебедева, Никитенко, 1998; Пещевицкая, 2010]. Многие барремские представители вида имеют более ассиметричную и неправильно треугольную форму, близкую к цератиоидной, что, наряду с отдельными особенностями табуляции, позволило рассматривать этот вид в составе рода Pseudoceratium [Bint, 1986; Harding, 1990]. Более поздние исследования показали, что вид A. anaphrissa обладает переходной морфологией между цератиоидными и ареолигеровыми формами [Пещевицкая, 2010].

\section{БИОСТРАТИГРАФИЧЕСКОЕ РАСЧЛЕНЕНИЕ РАЗРЕЗА ПО СПОРАМ И ПЫЛЬЦЕ НАЗЕМНЫХ РАСТЕНИЙ}

По спорам и пыльце наземных растений в разрезе Городищи установлено три слоя с палинофлорой (табл. 2). Распределение спор и пыльцы наземных растений по разрезу приведено на рис. 3, 4.

В нижней части разреза установлены слои с Selaginella granata. Спорово-пыльцевой комплекс, в основном, представлен таксонами широкого стратиграфического диапазона. Обилие пыльцы Classopollis и разнообразие спор глейхениевых папоротников характерны для верхнего келловея, кимериджа и нижней части волжского яруса на территории Восточно-Европейской платформы, Украине, юге Сибири, в Средней Азии и Крыму [Покровская, 1966; Болховитина, 1973; Добруцкая, 1973; Яновская, 1983; Шурыгин и др., 2000]. Споры глейхениевых папоротников с бугорчатой экзиной появляются на территории Восточно-Европейской платформы в келловее, а в верхнем оксфорде род Ornamentifera уже достигает значительного количества, до 14\% [Болховитина, 1973; Добруцкая, 1973]. Вид Ornamentifera echinata (Bolchovitina) Bolchovitina обнаружен в верхнем оксфорде Сибири [Никитенко и др., 2015]. Важным таксоном для биостратиграфии в этом регионе является вид Selaginella granata Bolchovitina, который появляется в середине нижнего кимериджа. В разрезе Городищи он появляется в верхах этого яруса. Отметим, что более низкие горизонты кимериджа в этом разрезе отсутствуют, поэтому определить точный уровень появления вида здесь невозможно.

Выше по разрезу, в слоях с Gleicheniidites toriconcavus, Plicatella chetaensis появляются споры схизейных папоротников с бугорчатой и ребристой скульптурой родов Concavissimisporites, Trilobosporites, Cicatricosisporites, Plicatella. Эти морфотипы появляются в верхнем оксфорде Сибири, Западной Европы, Северной Африки и Австралии, и в кимеридже и волжском/титонском ярусах продолжают встречаться достаточно редко [Batten, Koppelhus, 1996; Herngreen et al., 2000; Sajjadi, Playford, 2002; Schrank, 2010; Никитенко и др. 2015]. В составе этой группы в разрезе Городищи 
определены виды Cicatricosisporites sibiricus (Kara-Mursa) Chlonova и Plicatella chetaensis (Kara-Mursa) Bondarenko, появление которых ранее отмечалось в более высоких горизонтах: первого - в верхней части верхневолжского подъяруса на Северном Урале, второго - в бореальном берриасе на севере Сибири [Пещевицкая, 2010; Дзюба и др., 2018]. Следует отметить, что появление ребристых спор схизейных папоротников также наблюдается с зоны panderi на территории Днепрово-Донецкой впадины [Воронова, Яновская, 1973]. В основании описываемых слоев также появляется Gleicheniidites toriconcavus Krutzsch. Наиболее древние находки этого вида отмечаются в Германии с верхов верхней юры [Doring, 1965]. На территории Восточно-Европейской платформы он появляется в средней части волжского яруса, в слоях, датированных фауной [Добруцкая, 1973]. Важным стратиграфическим признаком можно также считать сокращение количества пыльцы Classopollis, что связано с постепенным окончанием позднеюрского этапа потепления климата [Покровская, 1966; Болховитина, 1973; Добруцкая, 1973; Ильина, 1985; Яновская, 1983; Шурыгин и др., 2000].

В готериве установлены слои с Cicatricosisporites stoveri, Gleicheniidites spp., Pinuspollenites spp. В основании появляется вид Cicatricosisporites stoveri Pocock. Ранее на территории европейской части России он отмечался с верхов баррема [Грязева, 1985]. Однако более поздние исследования показали, что этот вид появляется в средней части готерива в Сибири и Канаде [Burden, Hills, 1989; Пещевицкая, 2018]. Значительное увеличение количества спор глейхениевых папоротников, характерное для описываемых слоев, отмечается также в готериве Кавказа и северных районов Восточно-Европейской платформы: до 49\% и 60\% соответственно [Ярошенко, 1965; Добруцкая, 1973]. Н.А. Добруцкой приводятся данные, свидетельствующие о резком сокращение количества пыльцы Classopollis в валанжине и готериве на территории Восточно-Европейской платформы, что также является отличительным признаком комплекса спор и пыльцы в разрезе Городищи. На Кавказе количество этой пыльцы в готериве сокращается незначительно и продолжает оставаться достаточно высоким (5-35\%), что также наблюдается в одновозрастных отложениях Северного Прикаспия [Алексеева, 1973]. Низкие количественные показатели пыльцы хейролепидиевых характерны для валанжина и готерива Днепрово-Донецкой впадины [Воронова, 1971]. В этом районе и на Кавказе [Ярошенко, 1965] в готериве дополнительно наблюдается увеличение количества (до 15\%) и разнообразия пыльцы рода Pinuspollenites, что также характерно для одновозрастных отложений в разрезе Городищи. Однако готеривские комплексы спор и пыльцы на территории Украины отличаются меньшим количеством спор глейхениевых (в среднем 25\%) и значительно большим содержанием (30-36\%) и разнообразием (53 вида) спор схизейных папоротников. В разрезе Городищи разнообразие и количество спор схизейных в готериве также увеличивается, но в гораздо меньших пределах (15 видов, 1-5\%).

\section{ОБСУЖДЕНИЕ РЕЗУЛЬТАТОВ ПО БИОСТРАТИГРАФИИ}


Новое палинологическое изучение разреза Городищи позволило установить более полный систематический состав диноцист в верхнем кимеридже и волжском ярусе, в готериве диноцисты детально изучены впервые. Для кимериджа и нижневолжского подъяруса подтверждено биостратиграфическое расчленение, предложенное В.И. Ильиной [Riding et al., 1999]. Материалы автора позволили уточнить палинологическую характеристику границ и более надежно обосновать их стратиграфическое положение. Исчезновение видов Cribroperidinium angulosum, C. ehrenbergii, C.? "cauda", C.? "systremmatos" в верхней части зоны Gonyaulacysta jurassica subsp. jurassica и появление C.? edwardsii и Cometodinium whitei в основании следующей зоны, Corculodinium inaffectum, дает возможность проследить этот уровень в верхах верхнего кимериджа на территории Сибири, Англии, Франции и Багамского бассейна (табл. 3). Различные точки зрения на биостратиграфический объем и наполнение кимериджской части разреза Городищи в данном случае не влияют на обоснованность корреляций по диноцистам, так как корреляционный уровень приурочен к терминальной части этого интервала, который понимается достаточно однозначно [Герасимов, Михайлов, 1966; Силаков, 1984; Вишневская, Барабошкин, 2001; Scherzirger, Mitta, 2006; Rogov, 2010 и др.].

Анализ биостратиграфического распространения видов-индексов диноцистовых зон, выделенных ранее, показал, что они не обладают значительным корреляционным потенциалом, поскольку могут встречаться в более низких и/или высоких горизонтах. Таким образом, выделение диноцистовых био- и интервал-зон, основанных на появлении и исчезновении только видов-индексов, как это было предложено paнее [Riding et al., 1999], не всегда оправдано. В данной работе зоны и слои по диноцистам рассматриваются как биостратоны комплексного обоснования, что дает возможность более полно охарактеризовать стратиграфический интервал и выявить группы коррелятивных таксонов для определенных рубежей.

Именно такой подход позволил провести более детальное расчленение средней части волжского яруса (рис. 2; табл. 1). В верхней части зоны Glossodinium dimorphum выделены слои с Muderongia simplex. Поскольку не изучались диноцисты из нижней части зоны, точное положение основания слоев не установлено. Однако анализ биостратиграфического распространения диагностических таксонов показывает, что этот уровень имеет значительный корреляционный потенциал (табл. 3). Исчезновение Meiourogonyaulax bejui наблюдаются примерно на том же стратиграфическом уровне в Болгарии, а исчезновение Cribroperidinium crassinervum и появление M. simplex - на севере Западной Европы, причем последнее биособытие рассматривается как важный региональный биостратиграфический и корреляционный признак [Poulsen, Riding, 2003].

Верхняя граница слоев с M. simplex является одновременно кровлей зоны Glossodinium dimorphum, которая ранее определялась по исчезновению вида-индекса и формально совмещалась с кровлей аммонитовой зоны panderi [Riding et al., 1999]. Новые материалы подтвердили отсутствие вида-индекса в верхней части зоны panderi, и позволили выявить таксоны, которые имеют большее корреляционное значение (рис. 2, 
табл. 3). Их появление отмечается практически на том же уровне, что и исчезновение $G$. dimorphum. В соответствии с этим, верхняя граница зоны G. dimorphum смещена в верхнюю часть аммонитовой зоны panderi.

Вышележащие слои с Achomosphaera neptunii, Cribroperidinium hansenii охватывают среднюю часть средневожского подъяруса, по кровлю аммонитовой зоны virgatus (рис. 2). Верхняя часть волжского яруса соответствует зоне Gochteodinia villosa. Ее нижняя граница первоначально проводилась в основании аммонитовой зоны fulgens по появлению видаиндекса [Riding et al., 1999]. Однако последующие палинологические исследования показали, что он появляется ниже, в зоне nikitini [Harding et al., 2011]. Это также подтвердилось материалами автора и привело к пересмотру стратиграфического положения нижней границы зоны G. villosa (рис. 2). Таким образом, основание этой зоны прослеживается практически на одном стратиграфическом уровне на ВосточноЕвропейской платформе и севере Западной Европы (табл. 3). Дополнительно выявлено, что на этом уровне появляются представители рода Spiniferites, что позволяет проводить корреляцию как с северными, так и южными областями Западной Европы.

Следует отметить, что ранее в верхней части средневолжского подъяруса (аммонитовые зоны virgatus-nikitini) В.И. Ильина выделяла зону Senoniasphaera jurassica [Riding et al., 1999]. Однако анализ литературы и материалов автора показал, что вид $S$. jurassica имеет широкое стратиграфическое распространение, с верхнего оксфорда по готерив [Fauconnier, 1995; Iosifova, 1996; Никитенко и др., 2015]. Его акме также не полностью соответствует стратиграфическому диапазону этой зоны (рис. 2). В работе Я. Хардинга с соавторами [Harding et al., 2011] предложено альтернативное расчленение верхней части волжского яруса по палинологическим данным: аммонитовой зоне virgatus соответствует зона по диноцистам Periseiasphaeridium ingegerdia, в составе зоны Gochteodinia villosa выделено две подзоны (рис. 2). В качестве основы выбраны виды диноцист, которые рассматриваются как стратиграфически важные и имеющие высокий корреляционный потенциал для бореальных районов, что побудило авторов не только провести детальное расчленение разреза, но также пересмотреть и уточнить корреляцию аммонитовых зон Восточно-Европейской платформы и северных областей Западной Европы [Harding et al., 2011]. Такой подход вряд ли оправдан, так как юрские аммониты обладают значительно большими темпами эволюции, чем динофлагеллаты, что обеспечивает более детальное расчленение разрезов. $\mathrm{K}$ тому же, в качестве корреляционных признаков выбраны виды диноцист, которые, большей частью, имеют локальное стратиграфическое значение, так как их появление/исчезновение не прослеживается на означенных рубежах даже в пределах северных областей Западной Европы (табл. 4). На этой территории для выделения диноцистовых зон использованы биособытия, которые, в основном, имеют региональное значение, и только некоторые из них можно проследить примерно изохронно на Восточно-Европейской платформе: появление Muderongia simplex, Gochteodinia villosa и исчезновение Occisucista balios (рис. 2; табл. 1, 3). 
Биостратиграфическое расчленение верхней части волжского яруса в разрезе Городищи, предложенное автором, основано на палинологических признаках, которые прослеживаются в Сибири и Западной Европе на определенных рубежах и могут служить надежным обоснованием возраста даже при отсутствии аммонитовых датировок (табл. 3). Тем не менее, эти данные не вносят дополнительных корректив в понимание стратиграфического наполнения этой части разреза, хотя она является наиболее дискуссионной в этом отношении [Герасимов, Михайлов, 1966; Даин, Кузнецова, 1976; Вишневская, Барабошкин, 2001; Опорные разрезы..., 2010 и др.]: большая часть последней зоны средневолжского подъяруса и весь верхневолжский подъярус соответствуют распространению одной зоны по диноцистам (рис. 2).

В готериве важными биостратиграфическими маркерами являются начало количественных пиков Gardodinium trabeculosum и появление Aptea anaphrissa. Эти биособытия прослеживаются в средней части готерива практически циркумбореально: в Сибири, на Приполярном Урале, Восточно-Европейской платформе, севере Западной Европы, в Арктической Канаде [Pocock, 1976; Davey, 1979; Rawson, Riley, 1982; Aarhus et al., 1986; Heilmann-Clausen, 1987; Smelror et al., 1998; Лебедева, Никитенко, 1998; Пещевицкая, 2010; Никитенко и др., 2013]. На территории России - это интервал аммонитовой зоны versicolor, на севере Западной Европы - regale/inversum.

Изменение таксономического состава спор и пыльцы, а также их количественных показателей в разрезе Городищи, в целом, согласуется с закономерностями распределения наземных палиноморф в верхней юре и нижнем мелу в европейской части России, на Украине, Кавказе, в Средней Азии и Сибири [Покровская, 1966; Болховитина, 1973; Добруцкая, 1973; Яновская, 1983; Шурыгин и др., 2000; Никитенко и др., 2015]. Новые исследования и анализ литературных данных позволили установить ряд таксонов, которые могут считаться коррелятивными для определенных стратиграфических рубежей и служить более надежными индикаторами для детального биостратиграфического расчленения разрезов. Для средней части кимериджа важно появление вида Selaginella granata, что характерно для Сибири [Никитенко и др., 2015]. Его более позднее появление в разрезе Городищи может быть связано с отсутствием нижней и средней частей этого яруса в обнажении. Биостратиграфическим и корреляционным маркером нижней части средневолжского подъяруса на территории Восточно-Европейской платформы можно считать появление Gleicheniidites toriconcavus, что подтверждается материалами автора и H.А. Добруцкой [1973]. Примерно на этом же уровне (аммонитовая зона panderi) здесь появляются первые представители ребристых спор схизейных папоротников, что также прослеживается в Днепрово-Донецкой впадине [Воронова, Яновская, 1973]. Дополнительным признаком этого уровня является сокращение обилия пыльцы Classopollis, которое связано с началом общего похолодания климата и широко прослеживается в России и соседних регионах, хотя в количественных показателях может быть выражено по-разному в зависимости от района [Ярошенко, 1965; Покровская, 1966; Болховитина, 1973; Добруцкая, 1973; Яновская, 1983; Шурыгин и др., 2000; Никитенко и 
др., 2015 и др.]. Появление Cicatricosisporites stoveri можно рассматривать как палинологический признак средней части готерива: кроме разреза Городищи это также наблюдается в Сибири и Канаде [Burden, Hills, 1989; Пещевицкая, 2018].

\section{БИОФАЦИАЛЬНЫЙ АНАЛИЗ АССОЦИАЦИЙ МИКРОФИТОПЛАНКТОНА}

Результаты палеофациального анализа показывают, что в поздней юре и готериве осадки в разрезе Городищи, в основном, накапливались в умеренно глубоководных условиях неритовой зоны. Об этом свидетельствует почти постоянное доминирование морского микрофитопланктона в палинологических ассоциациях, высокий процент диноцист в его составе и их большое разнообразие (рис. 5).

Наибольшего разнообразия достигает семейство Gonyaulacaceae, в меньшей степени развиты - Cladopyхіасеаe, Pareodiniaceae и Areoligeraceae (рис. 2), что характерно для ассоциаций диноцист поздней юры и раннего мела в целом [Powell, 1992; Riding et al., 1999; Пещевицкая, 2010 и др.]. Среди празинофитов наибольшего количества достигает род Leiosphaeridia, иногда достаточно представительны роды Tasmanites и Pterospermella (рис. 5; табл. 1). Акритархи представлены акантоморфными родами Micrhystridium, Solisphaeridium, Veryhahium, а также шиповатыми формами, близкими по морфологии к празинофитам рода Leiosphaeridia, которые отнесены к формальному роду Lophosphaeridia.

В поздней юре иногда увеличивается количество акантоморфных акритарх, которое также сопровождается уменьшением общего количества микрофитопланктона и разнообразия диноцист, что является индикатором небольших регрессивных событий. Хорошо выраженное регрессивное событие в средней части кимериджского интервала подтверждается результатами фациального анализа фораминифер [Colpaert et al., 2017]. В это время также уменьшается количество диноцист рода Dingodinium, который рассматривается западноевропейскими палинологами как показатель глубоководной части неритовой зоны [Londeix, 1990; Leereveld, 1995 и др.]. Совместный фациальный анализ ассоциаций диноцист и фораминифер показал, что обилие этого рода может быть характерно и для умеренного глубоководья и контролироваться не только трансгрессивными событиями, но и повышением аэрации водных масс [Colpaert et al., 2017].

Интересно отметить, что количество диноцист рода Dingodinium значительно сокращается во второй половине фазы panderi, где по изотопным данным восстанавливаются слабо кислородные условия в осадке и периоды аноксии [Riboulleau et al., 2000, 2003 и др.]. Здесь же в ассоциациях микрофитопланктона увеличивается процентное содержание празинофитов, что в Западной Сибири типично для отложений, обогащенных органическим веществом, для которых предполагаются застойные придонные палеообстановки [Шурыгин и др., 2000; Ilyina et al., 2005; Никитенко и др., 2015; Nikitenko et al., 2018 и др.]. Это особенно характерно для баженовской свиты и ее аналогов. Совместные геохимические и микропалеонтологические (фораминиферы, 
палиноморфы) исследования волжско-берриасской части паксинской свиты в разрезе Нордвик (побережье моря Лаптевых) показали, что дизоксидные условия возникают на дне палеобассейна в результате поступления повышенного количества органического вещества из верхних водных слоев и его последующей переработки бактериями в донном осадке [Каширцев и др., 2018]. Таким образом, широкое развитие празинофитов отражает здесь высокую продуктивность фотической зоны, где некоторое снижение содержания кислорода возможно в результате жизнедеятельности многочисленных микроорганизмов. Это подтверждается и данными по разрезу Городищи: во второй половине фазы panderi одновременно с увеличением количества празинофитов наблюдается обилие мирофитопланктона в целом и сокращение процентного содержания диноцист рода Dingodinium, показателей аэрации водных масс (рис. 5). Геохимический анализ керогена и изотопные данные из этого интервала разреза также свидетельствуют, что органическое вещество здесь, в основном, имеет водорослевое происхождение [Riboulleau et al., 2000; Ruffell et al., 2002]. Однако распределено оно по разрезу неравномерно: слои со средним и низким содержанием органического вещества чередуются с более редкими высокоуглеродистыми прослоями. Сходную модель демонстрируют и палинологические данные (рис. 5).

Во второй половине фазы panderi возрастает количество диноцит простой морфологии групп Batiacasphaera/Espharisphaeridia и Barabatacysta/Pilosidinium, которые могут рассматриваться как индикаторы нестабильных условий в результате смены геохимических показателей или трансгрессивно-регрессивных событий [Никитенко и др., 2015; Jarvis et al., 1988; Nikitenko et al., 2018; Colpaert et al., 2017]. Для этого интервала можно предположить небольшие трансгрессии, поскольку здесь на некоторых уровнях увеличивается разнообразие диноцист и, одновременно, количество хоратных форм среди них. В первой половине фазы Achomosphaera neptunii, Cribroperidinium hansenii также наблюдается повышение количества диноцист подсемейства Leptodinioideae (до 7-9\% с 1.5-3\% по разрезу в целом), что характерно для трансгрессивной стадии на севере Сибири, наблюдающейся также в средней части волжского века [Никитенко и др., 2015]. В разрезе Городищи трансгрессия во второй половине фазы panderi дополнительно подтверждается изменениями в составе глинистых минералов и изотопными кривыми [Ruffell et al., 2002].

Отметим, что ранее для фазы panderi отмечались значительные изменения в таксономическом составе как макро-, так и микрофоссилий, что авторы интерпретировали как результат частых трансгрессивно-регрессивных событий [Vishnevskaya et al., 1999]. Новые палинологические исследования разреза Городищи показывают, что нестабильные условия в первой половине средневолжского времени возникали в результате изменения не только глубины палеобассейна, но также биопродуктивности фотической зоны и кислородных условий.

Однако интересно отметить, что максимальное количество микрофитопланктона, разнообразия диноцист, а также количества хоратных форм и представителей подсемейства Leptodinioideae (6.5-20.5\%) наблюдаются в верхней части средневолжского и 
нижней части верхневолжского подъярусов в песчанистых отложениях с обилием глауконита, которые свидетельствуют о регрессии и небольшой глубине палеобассейна (рис. 2, 5). Это, в первую очередь, можно объяснить более благоприятными температурными условиями, поскольку менее глубокий бассейн лучше прогревается, тем более что, что небольшой тренд потепления в конце средневолжского и в поздневолжское время восстанавливается по изотопным данным [Ruffel et al., 2002]. Изучение латерального распределения современных динофлагеллат показывает, что, в целом, они более разнообразны и обильны в тепловодных обстановках [Dale, 1996; Matthiessen et al., 2005; Sluijsa et al., 2005]. Хоратные формы обычно рассматриваются как показатель более глубоководных неритических условий [Leereveld, 1995; Dale, 1996]. Однако есть данные, подтверждающие, что некоторые хоратные диноцисты (Spiniferites, Systematophora) также присутствуют в мелководных и даже прибрежных обстановках, где могут достигать значительного количества [Omran et al., 1990; Wilpshaar, Leerveld, 1994; Sluijsa et al., 2005]. Фациальные изменения в составе хоратных форм наблюдаются и в разрезе Городищи. В фазу panderi количественные показатели распределяются более равномерно среди всех представителей этой группы. Позднее, в более мелководных обстановках количество хоратных форм возрастает, в основном, за счет родов Impletosphaeridium и Coronifera (рис. 5). Отметим, что на севере Сибири (разрез Оленек) содержание Impletosphaeridium также увеличивается во время небольшой регрессии в поздневолжское время [Nikitenko et al., 2018]. Количественный пик Coronifera совпадает с регрессивным событием в раннем апте разреза Хурлэндс в Англии [Lister, Batten, 1988]. Состав подсемейства Leptodinioideae в разрезе Городищи также изменяется с глубиной: в более глубоководных обстановках наиболее представительны диноцисты родов Leptodinium, Occisucysta, Tehamadinium, Scriniodinium, в более мелководных - Meiourogonyaulax, Lithodinia. На севере Сибири в трансгрессивные фазы количество этого подсемейства увеличивается за счет родов Scriniodinium и Sirmiodinium [Никитенко и др., 2015; Nikitenko et al., 2018]. Полученные результаты хорошо демонстрируют, что как количественные, так и качественные характеристики ассоциаций микрофитопланктона нельзя рассматривать изолированно как однозначные критерии определенных палеообстановок, необходим их комплексный анализ.

В готериве, в начале фазы versicolor по палинологическим данным восстанавливаются относительно глубоководные условия внутренней части неритовой зоны. Об этом свидетельствует небольшое количество микрофитопланктона, в составе которого все же преобладают диноцисты, достигающие значительного разнообразия. Относительно невысокую продуктивность фотической зоны и хорошую аэрацию водных масс можно предположить по небольшому количеству празинофитов и достаточно высокому содержанию форм, морфологически близких к роду Dingodinium, которые, видимо, замещают его в более мелководных условиях (рис. 5). Ранее диноцисты рода Chlamydophorella рассматривались как показатель глубокой части неритовой зоны [Londeix, 1990; Leereveld, 1995]. Данные по готериву Приполярного Урала показывают, 
что этот род также характерен для мелководно-морских отложений [Лебедева, Никитенко, 1998]. Одновременно, здесь присутствует значительное количество диноцист родов Gardodinium и Cassiculosphaeidia, что согласуется с результатами палеофациального изучения разреза Городищи.

Выше по разрезу количество микрофитопланктона возрастает, что может отражать трансгрессивный тренд. Однако в его составе начинают преобладать празинофиты. Как и в юре, это, вероятно, отражает увеличение продуктивности фотической зоны и возможность возникновения придонных обстановок с дефицитом кислорода.

\section{БИОФАЦИАЛЬНЫЙ АНАЛИЗ СПОРОВО-ПЫЛЬЦЕВЫХ АССОЦИАЦИЙ}

Палеофациальный анализ спорово-пыльцевых данных позволяет восстанавливать только общие тренды в изменении наземной растительности, поскольку споровопыльцевые ассоциации отражают лишь общие черты палеофлор на достаточно широкой территории и не могут свидетельствовать о точном соотношении растений-продуцентов, различающихся по пыльценосности (или спороносности). К тому же, к месту захоронения споры и пыльца приносятся ветром и водными потоками, при этом палиноморфы имеют разную способность к транспортировке и сохранению в осадке. Определение ботанической принадлежности ископаемых палиноморф часто бывает возможным только на уровне таксономических единиц среднего и высокого ранга (семейств, порядков), что предопределяет широкий спектр экологических параметров, которые отражают палинологические роды и виды. Тем не менее, палеофациальные исследования показывают, что спорово-пыльцевые данные позволяют восстанавливать определенные тренды в изменении климатических параметров, ландшафтов и общего состава древних растительных сообществ [Abbink, 1998; Van Konijnenburg-Van Cittert, 2002; Pestchevitskaya et al., 2012; Nikitenko et al., 2018 и др.].

В разрезе Городищи позднеюрские спорово-пыльцевые ассоциации с обилием пыльцы Classopollis (рис. 5) свидетельствуют о достаточно жарком и сухом климате, возможно с развитой сезонностью. Предполагается, что эта пыльца продуцировалась вымершими хвойными растениями семейства Cheirolepidiaceae, которые были представлены кустарниками или низкими деревьями, способными переносить засушливые периоды [Cornet, Traverse, 1975; Vakhrameev, 1991; Alvin, 1982; Abbink, 1998 и др.]. Однако эти растения, видимо, были представлены не только ксерофитами, поскольку некоторые данные указывают на то, что растения-продуценты пыльцы Classopollis могли также произрастать на влажных прибрежных территориях и участвовать в растительных сообществах мангров [Cornet, Traverse, 1975; Alvin, 1982; Abbink, 1998; Schrank, 2010; Pestchevitskaya et al., 2012]. Это позволяет предположить, что позднеюрские хейролепидиевые, продуцируя однотипную и морфологически простую пыльцу, были, тем не менее, достаточно разнообразны и включали растения, адаптированные к широкому спектру экологических условий, что позволило им широко освоить субтропические и тропические области. Их роль в древних растительных сообществах можно сравнить с 
той, которую сегодня занимают акациевые, представители которых также приспособлены к разнообразным условиям в областях с теплым климатом. В том числе, их кустарниковые и относительно низкорослые древесные формы являются характерными компонентами засухоустойчивой растительности тропических и субтропических саванн [Жизнь растений, 1978]. В поздней юре доминирование пыльцы Classopollis было также характерно для областей с тропическим и субтропическим климатом: она широко распространена на территории южных областей Сибири, Средней Азии, Кавказа, Крыма, Украины, Китая и Африки, где жаркий климат подтверждается данными литологии [Ярошенко, 1965; Пономаренко и др., 1973; Смирнова, 1983; Яновская, 1983; Ильина, 1985; Schrank, 2010; Lin, Li, 2019 и др.]. Существование достаточно жаркого климата в районе разреза Городищи косвенно подтверждается и палинспластическими построениями, которые показывают, что он находился в зоне 35-45º.ш. [Scotese, 2014], характеризующейся сегодня субтропическим климатом с чередованием сухих и влажных сезонов.

Влажные прибрежные участки были, вероятно, благоприятны для папоротников, которые в палинологических спектрах из разреза Городищи представлены, в основном, спорами глейхениевых (рис. 3, 5). Это также можно рассматривать как подтверждение существования сезонного климата. Для глейхениевых папоротников благоприятны влажные и теплые условия, в мезозое они могли доминировать в растительных сообществах влажных областей и даже болот [Болховитина, 1968; Бугдаева и др., 2006]. Однако, в целом, среди папоротников они наиболее адаптированы к сокращению влаги и могут переносить засушливые периоды. В влажных условиях они могут произрастать на возвышенностях и склонах, где иногда образуют монодоминантные заросли типа саванн или прерий [Жизнь растений, 1978; Van Konijnenburg-Van Cittert, 2002], что согласуется с обилием спор этих растений в разрезе Городищи.

В кимеридже увеличение количества спор глейхениевых и, одновременно, влаголюбивых компонентов может свидетельствовать о периоде с более влажным климатом. В это время также сокращается разнообразие палинологических ассоциаций, в основном, за счет пыльцы голосеменных, что может быть связано с меньшим разнообразием сухих местообитаний, к которым обычно адаптированы эти растения.

В целом, для кимериджа палинологические данные позволяют предполагать субтропическую растительность, адаптированную к аридному или семи-аридному климату со сменой сухих и влажных сезонов. Возвышенности, видимо, были заняты редколесьем или кустарниками из хейролепидиевых с зарослями травянистых глейхениевых папоротников. В древесной растительности влажных прибрежных участков также участвовали диптерисовые/циатейные папортники и гинковые. Подокарповых и древних представителей семейства сосновых, более характерных для умеренной зоны, крайне мало (рис. 4-5).

В волжском веке количество пыльцы Classopollis сокращается. Однако наряду с этим сохраняется значительное количество спор рода Plicifera среди глейхениевых и, 
иногда, пыльцы гинковых. Увеличение количества этих таксонов наблюдается во время потепления в конце юры на Северном Урале, где палинологические данные подтверждены результатами изотопных исследований [Дзюба и др., 2018]. Таким образом, общее сокращение теплолюбивых компонентов в разрезе Городищи незначительное, что отражает тенденцию к похолоданию климата, которое, тем не менее, в волжском веке не было существенным. Уменьшение количества пыльцы Classopollis в данном случае, видимо, связано с постепенной гумидификацией климата, что подтверждается увеличением долевого участия спор влаголюбивых папоротников и плаунов. Возможно, именно увеличение влажности климата и интенсивности химического выветривания повлекло за собой более обильный вынос питательных веществ с континента и обусловило высокую продуктивность фотической зоны, восстанавливаемую для этого периода по результатам палеоальгологического анализа.

Однако в литературе существует альтернативная точка зрения: на основе анализа состава глинистых минералов для интервала аммонитовой зоны panderi предполагается аридизация, хотя авторы сами отмечают, что это плохо согласуется с повышенным содержанием органического углерода, которое обычно связывают с гумидификацией и увеличением продуктивности фотической зоны [Ruffel et al., 2002; Kessels et al., 2003; Riboulleau et al., 2003]. Для объяснения этого парадокса авторы предлагают своеобразную модель, которая предполагает периодическое возрастание штормовой активности, приводящее к интенсивному перемешиванию водных масс, их обогащению железом за счет обильного поступления эоловых частиц, и, как результат, возникновению обстановок, благоприятных для расцвета микрофитопланктона. Новые палинологические данные показывают, что изменения в составе наземной растительности в этот период связаны не с аридизацией, а, напротив, с увеличением влажности, что хорошо согласуется с обилием органического углерода. Исследователи [Ruffel et al., 2002; Kessels et al., 2003; Riboulleau et al., 2003] также отмечают, что изменения в составе глинистых минералов могут быть связаны и с небольшим похолоданием. Это предположение подтверждается результатами фациального анализа спорово-пыльцевых ассоциаций.

В середине фазы Muderongia simplex наблюдается уменьшение разнообразия спор и пыльцы, которое, вероятно, связано с регрессией и освоением вновь образовавшихся прибрежных участков суши пионерной растительностью, представленной, в основном, глейхениевыми папоротниками, которые и сегодня легко осваивают новые пространства благодаря быстрому росту [Жизнь растений, 1978]. Сходная тенденция наблюдается также и во время регрессивного события готериве (рис. 5).

Для готеривского века показатели похолодания выражены более ярко: практически исчезает пыльца Classopollis, среди глейхениевых постепенно начинают доминировать представители рода Gleicheniidites, в составе древесной растительности значительную роль играют хвойные семейства сосновых, продуцирующие мешковую пыльцу (рис. 5). Влажность климата возрастает, что восстанавливается по увеличению количества спор влаголюбивых папоротников и плаунов. 


\section{ЗАКЛЮЧЕНИЕ}

Комплексное палинологическое изучение разреза Городищи, включающее биостратиграфический и биофациальный анализы таксономического состава морских и наземных палиноморф верхнего кимериджа, волжского яруса и готерива, позволило описать 8 палиностратонов по диноцистам и 3 палиностратона по спорам и пыльце наземных растений. В верхнем кимеридже и нижней части волжского яруса уточнена альгологическая характеристика диноцистовых зон, ранее установленных В.И. Ильиной, определены дополнительные критерии для обоснования их границ. Для средней части волжского интервала предложено более детальное расчленение. Впервые установлены слои с диноцистами в готериве и описана биостратиграфическая последовательность спорово-пыльцевых биостратонов для всего разреза. Анализ литературы и материалов автора показывают, что границы палиностратонов являются хорошими корреляционными маркерами. Корреляционные уровни по диноцистам прослеживаются в верхах кимериджа на территории Сибири, Англии, Франции и Багамского бассейна, в нижней, средней и верхней частях волжского яруса - в Сибири, Болгарии и на севере Западной Европы, в средней части готерива - практически циркумбореально (Сибирь, Приполярный Урал, север Западной Европы, Арктическая Канада). По спорам и пыльце наземных растений возможна корреляция в нижней части средневолжского подъяруса с Украиной (ДнепровоДонецкая впадина) и в средней части готерива с Сибирью и Канадой.

Результаты биофациального анализа микрофитопланктона свидетельствуют об умеренно глубоководных условиях неритовой зоны и хорошей аэрации водных масс. Небольшие регрессивные события восстанавливаются в позднем кимеридже и середине волжского века (фаза Muderongia simplex) и более значительное - в его конце. Более мелководные условия в поздневолжское время, вероятно, привели к лучшему прогреву воды в палеобассейне и возникновению благоприятных условий для развития динофлагеллат: таксономическое разнообразие их цист в ассоциациях резко возрастает. Во время трансгрессий в середине волжского века (фаза Achomosphaera neptuni, Cribroperidinium hansenii) и конце готеривского интервала периодически возникали придонные застойные условия в следствие бактериальной переработки органического вещества, поступающего из фотической зоны с высокой биопродуктивностью. На это указывает повышенное содержание празинофитов, а также сокращение количества диноцист рода Dingodinium и морфологически близких форм (Chlamydophorella, Stephanelytron, Gardodinium). В средней части волжского века это подтверждается геохимическими показателями. Отметим, что застойные условия для этого временного интервала характерны также для Сибири, где они восстанавливаются по аналогичной динамике в таксономическом составе ассоциаций микрофитопланктона и сходным геохимическим трендам. Вероятно, увеличение продуктивности фотической зоны могло быть вызвано обильным поступлением питательных веществ с континента в результате более интенсивного химического выветривания в условиях влажного климата. В разрезе 
Городищи взаимосвязь этих явлений подтверждается увеличением количества спор и пыльцы влаголюбивых растений во время трансгрессивных периодов, когда в ассоциациях микрофитопланктона были обильны празинофиты. В целом, по спорово-пыльцевым данным для юрского интервала восстанавливаются субтропические условия, в кимеридже аридные или семи-аридные, а волжском веке - более влажные. С середины волжского века начинается постепенное похолодание. В готериве эта тенденция становится более выраженной.

Автор выражает благодарность В.В. Митта за руководство полевыми работами и аммонитовую калибровку, А.В. Рябоконь за отбор образцов. Работа выполнена при финансовой поддержке гранта РНФ 18-17-00038 (основные исследования по биостратиграфии и биофациям), а также при научной поддержке проектов ФНИ № 03312019-0004 и IGCP-679, 632.

\section{ЛИТЕРАТУРА}

Алексеева В.И. Этапы развития флоры в юре и раннем мелу на территории восточной части Северного Прикаспия // Хлонова А.Ф. (Ред.) Палинология мезофита. Труды III Межд. палинологической конф. Москва, Наука, 1973, с. 112-117.

Болховитина Н.А. Споры глейхениевых папоротников и их стратиграфическое значение. М., Наука, 1968, 136 с.

Болховитина Н.А. Сравнительная характеристика палинологических комплексов поздней юры Русской платформы и Англии // Палинология мезофита. Труды III Междунар. палинологической конфер. Москва, Наука, 1973, с. 92-97.

Бугдаева Е.В., Волынец Е.Б., Голозубов В.В., Маркевич В.С., Амельченко Г.Л. Флора и геологические события середины мелового периода (Алчанский бассейн, Приморье). Владивосток, Дальнаука, 2006, 205 с.

Вишневская В.С., Барабошкин Е.Ю. Новые данные по стратиграфии лектостратотипа волжского яруса в деревне Городищи (среднее Поволжье) // Стратиграфия. Геол. корреляция, 2001, т. 9(5), с. 77-86.

Воронова М.А. Палинологическое обоснование стратиграфического расчленения нижнемеловых отложений Днепрово-Донецкой впадины. Киев, Наукова думка, 1971, 112 с.

Воронова М.А., Яновская Г.Г. Сопоставление спорово-пыльцевых комплексов пограничных юрско-меловых образований Днепрово-Донецкой впадины и междуречья ПрутДнепр // Палинология мезофита. Труды III Междунар. палинологической конфер. Москва, Наука, 1973, с. 101-104.

Герасимов П.А., Михайлов Н.П. Волжский ярус и единая стратиграфическая шкала верхнего отдела юрской системы // Изв. АН СССР. сер. геол. 1966 (2), с. 118-138.

Грязева А.С. Роль ребристых спор схизейных в палиностратиграфии нижнемеловых отложений северо-востока европейской части СССР // Палинологические исследования отложений палеозоя и мезозоя севера СССР и Прикаспия. Л., ВНИГРИ, 1985, с. 48-58.

Даин Л.Г., Кузнецова К.И. Фораминиферы стратотипа волжского яруса. М., Наука, 1976, 183 c.

Дзюба О.С., Пещевицкая Е.Б., Урман О.С., Шурыгин Б.Н., Алифиров А.С., Игольников А.Е., Косенко И.Н. Разрез Маурынья как ключевой для приграничных юрско- 
меловых отложений мелководно-морского генезиса в Западной Сибири // Геол. и геофизика. 2018, т. 59(7), с.1072-1102.

Добруцкая Н.А. Спорово-пыльцевые комплексы юрских и нижнемеловых отложений северных районов Русской платформы и их значение для стратиграфии и палеофлористики // Палинология мезофита. Труды III Междунар. палинологической конфер. Москва, Наука, 1973, с. 108-112.

Жизнь растений. В 6 томах. М., Просвещение, 1978, т. 4, 656 с.

Захаров В.А., Рогов М.А. Бореально-тетические миграции моллюсков на юрско-меловом рубеже и положение биогеографического экотона в северном полушарии // Стратиграфия. Геол. корреляция. 2002, т. 11(2), с. 54-74.

Ильина В.И. Палинология юры Сибири. М., Наука, 1985, 237 с.

Каширцев В.А., Никитенко Б.Л., Пещевицкая Е.Б., Фурсенко Е.А. Биогеохимия и микрофоссилии верхней юры и нижнего мела Анабарского залива моря Лаптевых // Геол. и геофизика, 2018, т. 59(4), с. 481-501.

Лебедева Н.К., Никитенко Б.Л. Микрофитопланктон и микрофораминиферы опорного разреза нижнего мела Приполярного Зауралья (Западная Сибирь) // Геол. и геофизика. 1998, т. 38 (6), c. 799-821.

Михайлов Н.П. Бореальные юрские аммониты (Dorsoplanitinae) и зональное расчленение волжского яруса. Труды ГИН, 1966 (151), 116 с.

Никитенко Б.Л., Шурыгин Б.Н., Князев В.Г., Меледина С.В., Дзюба О.С., Лебедева Н.К., Пещевицкая Е.Б., Глинских Л.А., Горячева А.А., Хафаева С.Н. Стратиграфия юры и мела Анабарского района (Арктическая Сибирь, побережье моря Лаптевых) и Бореальный зональный стандарт // Геол. и геофизика, 2013, т. 54(8), с. 1047-1082

Никитенко Б.Л., Князев В.Г., Пещевицкая Е.Б., Глинских Л.А. Верхняя юра побережья моря Лаптевых: межрегиональные корреляции и палеообстановки // Геол. и геофизика, 2015, т. 56(8), с. $1496-1519$.

Опорные разрезы верхней юры и нижнего мела района г. Ульяновска. Путеводитель экскурсий V Всерос. совещ. Ульяновск, УлГУ, 2010. 38 с.

Пещевицкая Е.Б. Диноцисты и палиностратиграфия нижнего мела Сибири. Новосибирск, Гео, 2010. 230 с.

Пещевицкая Е.Б. Палинологические последовательности готерива-альба на территории Гыданского района (север Западной Сибири) // Меловая система России и ближнего зарубежья: проблемы стратиграфии и палеогеографии. Белгород, ПОЛИТЕРРА, 2018, с. 218-222.

Покровская И.М. (Ред.) Палеопалинология. В 3 томах. 1966, т. 2, Л., Недра, 447 с.

Пономаренко 3.К., Бляхова С.М., Кальменева А.Х., Котова Л.И., Нестерова Е.В., Перфильева А.Р., Погодаева Т.В., Помумискова Л.Ш., Сакулина Г.В., Стукалова Н.И., Tерехова Е.К. Значение пыльцы Classopollis для стратиграфии юрско-палеогеновых отложений Казахстана и его палеофлористического районирования // Палинология мезофита. Труды III Междунар. палинологической конфер. М., Наука, 1973, с. 112-117.

Селькова Л.А., Ветошкина О.С. Результаты палинологических и изотопных исследований фоссилий из готеривских отложений разреза Городищи (Русская платформа) // Меловая система России и ближнего зарубежья: проблемы стратиграфии и палеогеографии. Краснодар, Кубанский гос. ун-т, 2012, с. 270-272. 
Силаков В.Н. (Ред.) Центральные районы Европейской части РСФСР. Сводный путеводитель экскурсий 059, 060, 066. М.: Наука, 1984. 135 с.

Смирнова С.Б. Палинокомплексы из пограничных юрско-меловых отложений Крыма, Кавказа, и Восточного Прикаспия // Стратиграфия и корреляция осадков методами палинологии. Труды IV Рос. палинологической конф., Свердловск, УНЦ, 1983, с. 134-138.

Шурыгин Б.Н., Никитенко Б.Л., Девятов В.П., Ильина В.И., Меледина С.В., Гайдебурова Е. А., Дзюба О.С., Казаков А.М., Могучева Н.К. Стратиграфия нефтегазоносныХ бассейнов Сибири. Юрская система. Новосибирск, «Гео», 2000, 480 с.

Яновская Г.Г. Палиностратиграфия юрских образований Днепрово-Прутского междуречья // Стратиграфия и корреляция осадком методами палинологии. Труды IV Рос. палинологической конф., Свердловск, УНЦ, 1983. с. 125-129.

Ярошенко О.П. Спорово-пыльцевые комплексы юрскаих и нижнемеловых отложений Северного Кавказа и их стратиграфическое значение. Труды ГИН, 1965 (117), 108 с.

Aarhus N., Verdenius J., Birkelund T. Biostratigraphy of a Lower Cretaceous section from Sklinnabanken, Norway, with some comments on the Andoya exposure Norsk Geologisk Tidsskrift // Norw. J. Geol., 1986, v. 66(1), p. 17- 43.

Abbink O.A. Palynological investigations in the Jurassic of the North Sea region. Utrecht, LPP Foundation, 1998, 192 p.

Alvin K.L. Cheirolepidiaceae: biology, structure and paleoecology // Rev. Palaeobot. Palynol., 1982, v. 37, p. 71-98.

Bailey D., Milner P., Varney T. Some dinoflagellate cysts from the Kimmeridge Clay Formation in North Yorkshire and Dorset, UK // Proceed. Yorkshire Geol. Soc., 1997, v. 51(3), p.235-243.

Batten D.J., Koppelhus E.B. Biostratigraphic significance of uppermost Triassic and Jurassic miospores in Northwest Europe // Palynology: Principles and Applications. Salt Lake City, ASSP, 1996, v. 2, p. 795- 806.

Benedek P.N. Phytoplanktonten aus dem Mittel- und Oberoligozän von Tönisberg (Niederrheingebiet) // Palaeontographica, Ab. B, 1972, v. 137, p.1-71.

Bint A.N. Fossil Ceratiaceae: a restudy and new taxa from the mid-Cretaceous of the Western Interior, USA // Palynology, 1986, v. 10, p.135-180.

Bujak P.J., Williams G.L. Cretaceous palynostratigraphy of offshore southeastern Canada // Geol. Surv. Canada, 1978, v. 297, p. 1-19.

Burden E.T., Hills L.V. Illustrated key to genera of Lower Cretaceous terrestrial palynomorphs (excluding megaspores) of Western Canada // AASP Contrib. Ser., 1989, v. 21, 147 p.

Colpaert C., Pestchevitskaya E.B., Nikitenko B.L. Upper Jurassic foraminifera, dinoflagellates and terrestrial sporomorphs from the Gorodishche Section (Ul'yanovsk Region, East European Platform, Russia): biostratigraphic, palaeoenvironmental and palaeobiogeographical implications // Rev. micropaleont. 2017, v. 60(4), p. 549-572.

Cornet B., Traverse A. Palynological contributions to the chronologyand stratigraphy of the Hartford Basin in Connecticut and Massachusetts // Geoscience and Man, 1975 (11), p. 1-33.

Courtinat B. Les organoclastes des formations lithologiques du Malm dans le Jura meridional. Systematique, biostratigraphie et elements d'interpretation paleoecologique // Labor. Geol. Fac. Sci. Lyon, 1989, v. 105, p. 1- 361. 
Courtinat B. Review of the dinoflagellate cyst Subtilisphaera? inaffecta (Drugg, 1978) Bujak \& Davies, 1983 and S.? paeminosa (Drugg, 1978) Bujak \& Davies, 1983 // J. Micropal., 2000, v.19(2), p.165-175.

Dale B. Dinoflagellate cyst ecology: modeling and geological applications // Palynology: principales and application. Salt Lake City, ASSP, 1996, v. 3, p. 1249-1277.

Davey R.J. The stratigraphic distribution of dinocysts in the Portlandian (Latest Jurassic) to Barremian (Early Cretaceous), of northeast Europe // ASSP Contributions Series, 1979, v. 2(5), p. 49- 81

Davey R.J. Dinocysts stratigraphy of the latest Jurassic to Early Cretaceous of the Haldager No.1 borehole, Denmark // Denm. Geol. Unders., Ser. B, 1982 (6), p. 1-56.

Dodekova L. Dinoflagellate cysts from the Bathonian-Tithonian (Jurassic) of North Bulgaria. III. Tithonian dinoflagellate cysts // Geol. Balcan., 1994, v. 24(5), p. 11-46.

Doring H. Die sporenpalaontologische Gliederung des Wealden in Westmecklenburg (Struktur Werle) // Geologie, 1965, v. 47, p. 1-119.

Duxbury S. A palynostratigraphy of the Berriasian to Barremian of the Speeton Clay of Speeton, England // Palaeontographica, Ab. B, 1977, v. 160(1), p. 17-67.

Dybkjaer K. Palynological dating of the Mandal Formation (Uppermost Jurassic - Lowermost Cretaceous, Norwegian Central Graben) and correlation to organic-rich shales in the Danish sector // Marine Petrol. Geol., 1998, v. 15(6), p. 495-503.

Fauconnier D. Palynologie du stratotype de l'Hauterivien. Rapport du Bureau de Recherches Geologiques et Minieres. Orlean, Service Geologique National, 1982, V. 82, 24 p.

Fauconnier D. Jurassic palynology from a borehole in the Champagne Area, France. Correlation of the Lower Callovian - Middle Oxfordian using sequence stratigraphy // Rev. Palaeobot. Palynol., 1995, v. 87(1), p. 15-26.

Gitmez G.U., Sarjeant W.A.S. Dinoflagellate cysts and acritarchs from the Kimmeridgian, (Upper Jurassic), of England, Scotland and France. Bulletin of British Museum (National Hystory) // Geology, 1972, v. 21(5), p. 175-257.

Habib D., Drugg W.S. Dinoflagellate age of Middle Jurassic — Early Cretaceous sediments in the Blake-Bahama Basin // Initial Rep. Deep Sea Drill. Project, 1983, v. LXXVI, p. 623—638.

Hantzpergue P., Baudin F., Mitta V., Olferiev A., Zakharov V. The Upper Jurassic of the Volga Basin: ammonite biostratigraphy and occurrence of organic-carbon rich facies. Correlations between boreal-subboreal and submediterranean provinces // Mem. Mus. Nature Hist. Nat., 1998, v.1 79, p. 9-33.

Harding I.C. An early Cretaceous dinocyst assemblage from the Wealden of Southern England // Studies in Palaeontology and Palynology in honor of N.E. Hughe. Special Papers in Palaeontology, 1986, v. 35, p. 95-109.

Harding I.C. A dinocyst calibration of the European Boreal Barremian // Palaeontographica, Ab. B, 1990, v. 218, p.1-76.

Harding I.C., Smith G.A., Riding J.B., Wimbledon W.A.P. Inter-regional correlation of Jurassic/Cretaceous boundary strata based on the Tithonian-Valanginian dinoflagellate cyst biostratigraphy of the Volga Basin, western Russia // Rev. Palaeobot. Palynol., 2011, v. 167, p. 82-116.

Heilmann-Clausen C. Lower Cretaceous dinoflagellate biostratigraphy in the Danish Central Trough // Denm. Geol. Unders., 1987, v. 17, p. 1-89.

Herngreen G.F.W., Felder W.M., Kedves M., Meessen J.P.M.T. Micropaleontology of the Maestrichtian in borehole Bunde, the Netherlands // Rev. Palaeobot. Palynol., 1986, v. 48, p. 1-70. 
Herngreen G.F.W., Kerstholt S.J., Munsterman D.K. Callovian-Ryazanian (Upper Jurassic) palynostratigraphy of the Central North Sea Graben and Vlieland Basin, the Netherlands // Mededel. Nederl. Instit. Toegepaste Geowetenschappen, 2000, v. 63, p. 1-97.

Ilyina V.I., Nikitenko B.L., Glinskikh L.A. Foraminifera and dinoflagellate cyst zonation and stratigraphy of the Callovian to Volgian reference section in the Tyumenskaya superdeep well (West Siberia, Russia) // Recent developments in applied biostratigraphy. Micropalaeontol. Soc., Spec. Publ., 2005, p. 109-144.

Iosifova E.K. Dinocysts from Tchernaya Retchka (Ryazanian-Aptian, Lower Cretaceous) of the Moscow Basin, Russia // Rev. Palaeobot. Palynol., 1996, v. 91(1), p. 187-240.

Jarvis I., Carson G.A., Cooper M.K.E., Hart M.B., Leary P.N., Tocher B.A., Horne D., Rosenfeld A. Microfossil assemblages and the Cenomanian-Turonian (Late Cretaceous) oceanic anoxic event // Cretaceous Res., 1988, v. 9, p. 3-103.

Jenkins W.A.M., Ascoli P., Grandstein F.M., Williams G.L. Stratigraphy of the Acomo IOE A-I Puffin B-90 well, Grand Banks of Newfounland // Geol. Surv. Canada, 1974, v. 74-61, p. 1-12.

Kessels K., Mutterlose J., Ruffell A. Calcareous nannofossils from late Jurassic sediments of the Volga Basin (Russian Platform): evidence for productivity-controlled black shale deposits // Int. J. Earth Sci. (Geol. Rundsch.), 2003, v. 92, p. 743-757.

Koevoets M.J., Hammer O., Olaussen S., Senger K., Smelror M. Integrating subsurface and outcrop data of the Middle Jurassic to Lower Cretaceous Agardhfjellet Formation in central // Norweg. J. Geol., 2018, v. 98, p. 1-34.

Kunz R. Phytoplankton und Palynofazies im Malm NW-Deutschlands (Hannoversches Bergland) // Palaeontographica, Ab. B, 1990, v. 216(1), p. 1-105.

Leereveld H. Dinoflagellate cysts from the Lower Cretaceous Rio Argossuccession (SE Spain). Utrecht, LPP Foundation, 1995, 175 p.

Leereveld H. Upper Tithonian - Valanginian (Upper Jurassic - Lower Cretaceous) dinoflagellate cyst stratigraphy of the western Mediterranean // Cretaceous Res., 1997, v. 18(4), p. 385-420.

Lin M., Li J. Late Jurassic-Early Cretaceous palynofloras in the Lhasa Block, central Xizang, China and their bearing on palaeoenvironments // Palaeogeogr., Palaeoclimatol., Palaeoecol., 2019, v. 515, p. 95-106.

Lister J.K., Batten D.J. Stratigraphic and palaeoenvironmental distribu-tion of Early Cretaceous dinoflagellate cysts in the Hurlands Farm Borehole,West Sussex. England // Palaeontographica, Ab. B, 1988, v. 210(1/3), p. 9-89.

Londeix L. La distribution des kystes de dinoflagelles dans hemipelag-iques, (Ardeche), et pelagiques, (Arc de Castellane, S.R. de la France), en Domaine Voranien, du Valanginien terminal au Barremien inferieur. In 2 volumesBordeaux, , L’Universite de Bordeaux, 1990. V. 1, 279 p.

Lord A.R., Cooper M.K.E., Corbett P.W.M., Fuller N.G., Rawson P.F., Rees A.J.J. Microbiostratigraphy of the Volgian Stage (Upper Jurassic), Volga River, USSR // N. Jb. Geol. Palaontol. Monatsh., 1987, v. 10, p. 577-605.

Matthiessen J., de Vernal A., Head M., Okolodkov Y., Zonneveld K., Harland R. Modern organic-walled dinoflagellate cysts in Arctic marine environments and their paleoenvironmental significance // Palaontol. Zeitsch., 2005, v. 79(1), p. 3-51.

Nikitenko B.L., Pestchevitskaya E.B., Khafaeva S.N. High-resolution stratigraphy and palaeoenvironments of the Volgian-Valanginian in the Olenek section (Anabar-Lena region, Arctic Eastern Siberia) // Rev. Micropalaeontol., 2018, v. 61, p. 271-312. 
Nohr-Hansen H. Dinocyst stratigraphy of the Lower Kimmeridge Clay, Westbury, England // Medede. Dansk Geol. Forening Bull., 1986, v. 35. p. 31-51.

Nohr-Hansen H. Dinoflagellate cyst stratigraphy of the Barremian to Albian, Lower Cretaceous, North-East Greenland // Gronlands Geol. Unders., 1993, v. 166, p. 1-171.

Omran A.M., Soliman H.A, Mahmoud M.S. Early Cretaceous palynology of three boreholes from northern Western Desert (Egypt) // Rev. Palaeobot. Palynol., 1990, v. 66, p. 293-312.

Partington M.A., Mitchener B.C., Milton N.J., Fraser A.J.B. Genetic sequence stratigraphy for the North Sea Late Jurassic and Early Cretaceous: distribution and prediction of Kimmeridgian-Late Ryazanian reservoirs in the North Sea and adjacent areas // Petroleum Geology of Northwest Europe: Proceedings of the 4th Conference of Petroleum Geology. London, Geological Society, 1993, p. 347-370.

Pestchevitskaya E.B., Smokotina I.V., Baykalova G.E. Lower Valanginian palynostratigraphy of southeastern regions of Siberia, palaeoenvironment and vegetation reconstructions // J. Stratigr., 2012, v. 36(2), p. 179-193.

Pocock S.A.J. A preliminary dinoflagellate zonation of the Uppermost Jurassic and Lower part of the Cretaceous, Canadian Arctic, and possible correlation in the Western Canada Basin // Geosci. and Man, 1976, v. 15, p. 101-114.

Poulsen N.E., Riding J.B. Jurassic dinoflagellate cyst zonation of Sub-boreal Northwest Europe // Surv. Denm. Greenl., 2003 (1), p. 115-144.

Poulsen N.E. Dinoflagellate cysts from marine Jurassic deposits of Denmark and Poland // AASP Contributions Series, 1996, v. 31, p. 1-227.

Poulsen N.E. Dinoflagellate cyst biostratigraphy of the Oxfordian and Kimmeridgian of Poland // Acta Geol. Polonica, 1993, v. 43(3), p. 251-272.

Powell A.J. (Ed.) A stratigraphic index of dinoflagellate cysts. London, Chapmanand Hall, 1992, $290 \mathrm{p}$.

Rawson P.F., Riley L.A. Latest Jurassic - Early Cretaceous events and the "Late Cimmerian" unconformity” in the North Sea area // AAPG Bull., 1982, v. 66(12), p. 2628-2648.

Riboulleau A. Géochimie des black shales du Jurassique supérieur de la plateforme Russe // Processus de sédimentation et de préservationde la matière organique. Paris, Université de Paris, 2000, $272 \mathrm{p}$.

Riboulleau A., Baudin F., Deconinck J.-F., Derenne S., Largeau C., Tribovillard N. Depositional conditions and organic matter preservation pathways in an epicontinental environment: the Upper Jurassic Kashpir Oil Shales (Volga Basin, Russia)// Palaeogeogr., Palaeoclimatol., Palaeoecol., 2003, v. 197, p. 171-197.

Riding J.B. The Jurassic dinoflagellate cyst Gonyaulacysta dentata (Raynaud 1978) Lentin et Vozzhennikova 1990 emend. nov.: an index species for the Late Callovian to earliest Oxfordian of the northern hemisphere // Rev. Palaeobot. Palynol., 2012, v. 176-177, p. 68-81.

Riding J.B., Federova V.A., Ilyina V.I. Jurassic and lowermost Cre-taceous dinoflagellate cyst biostratigraohy of the Russian Platform andnorthern Siberia, Russia // AAPS Contrib. Ser., 1999, v. 36, $184 \mathrm{p}$.

Riding J.B., Thomas J.E. Dinoflagellate cyst stratigraphy of the Kimmeridge Clay, (Upper Jurassic) from the Dorset Coast, southern England // Palynology, 1988, v. 12, p. 65-88.

Rogov M. A precise ammonite biostratigraphy through theKimmeridgian-Volgian boundary beds in the Gorodischi section (MiddleVolga area, Russia), and the base of the Volgian Stage in its type area // Volumina Jurassica, 2010, v. 8, p. 103-130. 
Ruffell A.H., Price G.D., Mutterlos J., Kessels K., Baraboshkin E., Gröcke D.R. Palaeoenvironmental sensitivity of clay minerals, stable isotopesand calcareous nannofossils: evidence for palaeoclimatic change during theLate Jurassic-Early Cretaceous, Volga Basin, SE Russia // Geol. J., 2002, v. 37, p. 17-33.

Sajjadi F., Playford G. Systematic and stratigraphic palynology of Late Jurassic - earliest Cretaceous strata of the Eromanga Basin, Queensland, Australia, Part two // Palaeontographica, 2002, v. 261, p. 99-165.

Sarjeant W.A.S. Middle and Upper Jurassic dinoflagellate cyst // AASP Contrib. Ser., 1979, v. 2(5), p. 133-156.

Scherzirger A., Mitta V.V. New data on ammonites and stratigraphy of the Upper Kimmeridgian and Lower Volgian (Upper Jurassic) of the middle Volga Region (Russia) // N. Jb. Geol. Palaont. Abh., 2006 v. 241(2), p. 225-251.

Schnyder J., Deconinck J.-F., Baudin F., Colombie C., du Chene R.J., Gardin S., Galbrun B., de Rafelis M. Purbeck beds (Late Jurassic) in the Phare de Chassiron section (Ile d'Oleron, NW Aquitaine Basin, France): Refined age-assignment and long-term depositional sequences // Geobios, 2012, v. 45, p. 485-499.

Schrank E. Pollen and spores from the Tendaguru Beds, Upper Jurassic and Lower Cretaceous of southeast Tanzania: palynostratigraphical and paleoecological implications // Palynology, 2010, v. 34(1), p. 3-42.

Scotese C.R. Atlas of Jurassic paleogeographic maps, the Jurassic and Triassic, PALEOMAP Project. Evanston, IL, 2014, maps 32-42.

Sluijsa A., Pross J., Brinkhuis H. From greenhouse to icehouse; organic-walled dinoflagellate cysts as paleoenvironmental indicators in the Paleogene// Earth-Sci. Rev., 2005, v. 68, p. 281-315.

Smelror M. Mork A., Monteil E., Rutledge D., Leereveld H. The Klippfisk Formation: A new lithostratigraphic unit of Lower Cretaceous platform carbonates on the western Barents Shelf // Polar Res., New Ser., 1998, v. 17(2), p. 181-202.

Smelror M., Dypvik H. Marine microplankton biostratigraphy of the Volgian - Ryazanian boundary strata,western Barents Shelf // Norges geol. Unders., 2005, v. 443, p. 61-69.

Smith G.A., Harding I.C. New dinoflagellate cyst species from Upper Jurassic to Lower Cretaceous sediments of the Volgian lectostratotype sections at Gorodische and Kashpir, Volga Basin, Russia // Rev. Palaeobot. Palynol., 2004, v. 128, p. 355-379.

Stoian L.M. Late Cretaceous - Late Eocene palynofloras from drillhole Troas 1, offshore Otway Basin, South Australia. Minerals and Energy Resources. Government of South Australia // Report Book, 2002, v. 10, p. 1-21.

Vakhrameev V.A. Jurassic and Cretaceous Floras and Climates of the Earth. Cambridge, Cambridge University Press, 1991, 318 p.

Van Konijnenburg-Van Cittert J.H.A. Ecology of some Late Triassic to Early Cretaceous ferns in Eurasia // Rev. Palaeobot. Palynol., 2002, v. 119, p. 113-124.

Vishnevskaya V.S., De Wever P., Baraboshkin E.Y., Bogdanov N.A., Bragin N.Y., Bragina L.G., Kostyuchenko A.S., Lambert E., Malinovsky Y.M., Sedaeva K.M., Zukova G.A. New stratigraphic and palaeogeographic data on Upper Jurassic to Cretaceous deposits from the eastern periphery of the Russian Platform (Russia) // Geodiversitas, 1999, v. 21(3), p. 347-363.

Williams G.L., Bujak J.P. Palynological stratigraphy of Deep Sea Drilling Project site 416 // Init. Rep. Deep Sea Drill. Proj., 1980, v. 50, p. 467-495. 
Wilpshaar M., Leereveld H. Palaeoenvironmental changes in the Early Cretaceous Vocontian Basin (SE France) reflected by dinoflagellate cysts // Rev. Palaeobot. Palynol., 1994, v. 84, p. 121-128.

Zotto M., Drugg W.S., Habib D. Kimmeridgian dinoflagellate stratigraphy in the Southwestern North Atlantic // Micropaleontol., 1987, v. 33(3), p. 193-213. 


\section{Объяснение к рисункам.}

Рис. 1. Расположение разреза Городищи.

Рис 2 (начало и продолжение). Распределение диноцист в разрезе Городищи и его биостратиграфическое расчленение в сравнении с результатами предшествующих палеоальгологических исследований и последовательностями диноцистовых зон севера Западной Европы (условные обозначения см. на рис. 3; серыми линиями показаны образцы слабо насыщенные микрофитопланктоном; красным и голубым цветом отмечены стратиграфически важные таксоны).

Рис. 3. Распределение спор наземных растений в разрезе Городищи и его биостратиграфическое расчленение (серыми линиями показаны образцы слабо насыщенные палиноморфами наземного генезиса; красным и голубым цветом отмечены стратиграфически важные таксоны).

Рис. 4. Распределение пыльцы наземных растений в разрезе Городищи и его биостратиграфическое расчленение (условные обозначения см. на рис. 3; серыми линиями показаны образцы слабо насыщенные палиноморфами наземного генезиса; красным и голубым цветом отмечены стратиграфически важные таксоны).

Рис. 5. Количественное соотношение некоторых экологических групп морских и наземных палиноморф в разрезе Городищи и фациальные особенности.

Примечание: среди теплолюбивых компонентов в составе группы «другие» рассматриваются - Dictyophyllidites, Tripartina, Lakhnavitriletes, Duplexisporites, Kluckisporites, Sciadopityspollenites, Eucommiidites, Quadraeculina.

\section{Объяснение к таблицам.}

Табл. 1. Палинологическая характеристика биостратиграфических подразделений по диноцистам.

Табл. 2. Палинологическая характеристика слоев со спорами и пыльцой.

Табл. 3. Анализ корреляционного значения видов диноцист, использованных для палинологического обоснования биостратиграфических подразделений по диноцистам (жирным шрифтом отмечены биособытия, имеющие значительный корреляционный потенциал).

Табл. 4. Анализ корреляционного значения видов диноцист, использованных Я. Хардингом с соавторами для палинологического обоснования зон по диноцистам (жирным шрифтом отмечены биособытия, имеющие значительный корреляционный потенциал). 


\begin{tabular}{|c|c|c|}
\hline $\begin{array}{c}\text { Название } \\
\text { палино- } \\
\text { стратона, } \\
\text { мощность } \\
\end{array}$ & Обоснование границ & Характерный комплекс \\
\hline $\begin{array}{l}\text { Зона } \\
\text { Gonyau- } \\
\text { lacysta } \\
\text { jurassica } \\
\text { subsp. } \\
\text { jurassica } \\
\text { (ДК Gr1); } \\
\text { мощность } \\
3.5 \text { м }\end{array}$ & $\begin{array}{l}\text { Нижняя не прослежена } \\
\text { и определяется началом } \\
\text { разреза, верхняя прово- } \\
\text { дится по исчезновению } \\
\text { Gonyaulacysta jurassica } \\
\text { subsp. jurassica и появ- } \\
\text { лению Cribroperidinium? } \\
\text { edwardsii. }\end{array}$ & $\begin{array}{l}\text { Доминируют диноцисты рода Dingodinium (10-43\%) и группы Escharisphaeridia-Batiacasphaera (7-26\%). } \\
\text { Многочисленны виды Dingodinium jurassicum (3-8\%) и D. albertii (7-22\%). Постоянно присутствуют } \\
\text { проксиматные диноцисты плохой сохранности (1-5\%), группы Sentusidinium-Barbatacysta (0.5-5.5\%), виды } \\
\text { Dingodinium tuberosum (1-3,5\%), Pareodinia ceratophora (0.5-1\%), Cribroperidinium granuligerum (1-2\%), C. } \\
\text { globatum (1-2\%), C. angulosum (1-3.5\%), Apteodinium maculatum, Occisucysta balios (0.5-1\%), O. } \\
\text { monoheuriskos (0.5-1\%), Escharisphaeridia granulata (0.5-1\%), E. pocockii (0.5-2.5\%), E. psilata (1-8\%), E. rudis } \\
\text { (0.5-1\%), E. dicrypta, Barbatacysta brevispinosa (0.5-1\%), B. pilosa (0.5-1\%), Circulodinium deflandrei (0.5-5\%), } \\
\text { C. copei (0.5-2.5\%), Cyclonephelium "palliatum" (0.5-1\%), Chlamydophorella nyei (0.5-1\%), Cassiculasphaeridia } \\
\text { magna (0.5-1\%). В нижней части зоны единично встречаютс Cribroperidinium ehrenbergii, C.? "cauda" , C.? } \\
\text { "systremmatos". Разнообразны диноцисты групп Escharisphaeridia-Batiacasphaera, Sentusidinium-Barbatacysta, } \\
\text { Circulodinium-Cyclonephelium и родов Gonyaulacysta, Cribroperidinium, Leptodinium, Meiourogonyaulax. Среди } \\
\text { акритарх наиболее многочисленны Michrystridium (0.5-15\%). Присутствют M. “deflandrei”, M. rarispinum, M. } \\
\text { fragile, M. inconspicuum, M. minutispinum, Solisphaeridium stimuluferum, Veryhachium formosum, V. europeum, V. } \\
\text { brevispinum, V. downiei. Достаточно обильны празинофиты Leiosphaeridia (5-19\%), постоянно присутствуют } \\
\text { Pterospermella (0,5-2\%), Cутаtiosphaera (0,5-2\%), Tasmanites (0,5-1\%). Oпределены C. parva, C. eupeplos, P. } \\
\text { australiensis, P. gracilis, P. undulata, P. helios. }\end{array}$ \\
\hline $\begin{array}{l}\text { Зона Corcu- } \\
\text { lodinium } \\
\text { inaffectum } \\
\text { (ДК Gr2); } \\
\text { мощность } \\
5.5 \text { м }\end{array}$ & $\begin{array}{l}\text { Нижняя - по исчезно- } \\
\text { вению Gonyaulacysta } \\
\text { jurassica subsp. juras- } \\
\text { sica и появлению } \\
\text { Cribroperidinium? ed- } \\
\text { wardsii, верхняя - по } \\
\text { прекращению посто- } \\
\text { янного присутствия и } \\
\text { количественному сокра- } \\
\text { щению Corculodinium } \\
\text { inaffectum. }\end{array}$ & $\begin{array}{l}\text { Доминирование Dingodinium (33-60.5\%) становится более выраженным. Увеличивается количество D. } \\
\text { jurassicum (3-29\%) и D. albertii (7-24\%), D. tuberosum (1-6\%), а также диноцист группы Sentusidinium- } \\
\text { Barbatacysta (2-11\%). Сохраняется разнообразие родов Gопyaulacysta, Cribroperidinium, Leptodinium, } \\
\text { Meiourogonyaulax, группы Escharisphaeridia-Batiacasphaera, но их процентное содержание сокращается. } \\
\text { Постоянные компоненты - проксиматные диноцисты плохой сохранности (1-4.5\%), Lithodinia arcanitabulata, } \\
\text { O. monoheuriskos, Escharisphaeridia granulata, E. pocockii, E. rudis, Barbatacysta pilosa (0.5-1.5\%), } \\
\text { Sentusidinium villersense (1-3\%), Corculodinium inaffectum (0.5-4.8\%). Появляются Cribroperidinium? edwardsii, } \\
\text { Cometodinium whitei. Присутствуют празинофиты Pterospermella и Tasmanites, акритархи Solisphaeridium, } \\
\text { Veryhachium, Michrystridium (0.5-7\%), но количество последнего сокращается. Меньше празинофитов } \\
\text { Leiosphaeridia (5-12.5\%) и Cymatiosphaera (0.5\%). }\end{array}$ \\
\hline $\begin{array}{l}\text { Слои с Мu- } \\
\text { derongia } \\
\text { simplex } \\
\text { (ДК Gr3б); } \\
\text { мощность } \\
5.5 \text { м }\end{array}$ & $\begin{array}{l}\text { Нижняя проводится по } \\
\text { появлению Mидеrongia } \\
\text { simplex. На этом же } \\
\text { уровне } \quad \text { исчезают } \\
\text { Cribroperidinium crass- } \\
\text { inervum, Meiourogo- } \\
\text { nyaulax bejui. Bерхняя } \\
\text { проводится по появле- } \\
\text { нию Stiphrosphaeridium } \\
\text { dictyophorum, Dingodi- } \\
\text { nium spinosum, Cribro- } \\
\text { peridinium hansenii. }\end{array}$ & $\begin{array}{l}\text { Доминируют диноцисты рода Dingodinium (21.5-63.5\%). Достаточно многочисленны проксиматные } \\
\text { диноцисты плохой сохранности (5.5-17\%), групп Escharisphaeridia-Batiacasphaera (4-12\%) и Sentusidinium- } \\
\text { Barbatacysta (0.5-11\%), виды D. jurassicum (1-10\%) и D. albertii Sarjeant (2.5-13.5\%), D. tuberosum (Gitmez) } \\
\text { Fisher and Riley (0.5-10\%). Иногда значительного количества достигает Occisucysta monoheuriskos (до 5\%). В } \\
\text { основании слоев появляется вид Muderongia simplex, вблизи кровли - Kleithriasphaeridium porosispinum } \\
\text { Davey. Постоянно присутствуют Cribroperidinium globatum (0.5-5\%), Escharisphaeridia granulata, E. pocockii, } \\
\text { E. rudis, Barbatacysta pilosa (Ehrenberg) Courtinat (0.5-1.5\%), Circulodinium copei Bailey et al. (1-2.5\%), } \\
\text { Chlamydophorella spp. (0.5-3\%), Cometodinium spp. Paзнообразны poды Gonyaulacysta, Cribroperidinium, } \\
\text { Leptodinium, Meiourogonyaulax, диноцисты групп Escharisphaeridia-Batiacasphaera и Sentusidinium- } \\
\text { Barbatacysta. Среди акритарх постоянно встречаются представители родов Solisphaeridium (0.5-3\%), } \\
\text { Michrystridium (0.5-3\%). Среди празинофитов наибольшего количества достигает pод Leiosphaeridia (9.5- } \\
\text { 13.5\%). В меньшем количестве определены Pterospermella (0-6\%), Cymatiosphaera (0-7\%), Tasmanites (0- } \\
\text { 3.5\%). }\end{array}$ \\
\hline $\begin{array}{l}\text { Слои с } \\
\text { Achomo- } \\
\text { sphaera } \\
\text { neptuni, } \\
\text { Cribrope- } \\
\text { ridinium } \\
\text { hansenii } \\
\text { (ДК Gr4); } \\
\text { мощность } \\
5 \text { м }\end{array}$ & $\begin{array}{l}\text { Нижняя проводится по } \\
\text { появлению } \\
\text { Stiphrosphae-ridium } \\
\text { dictyopho-rum, Dingodini } \\
\text { um spino-sum, } \\
\text { Cribroperidinium } \\
\text { hansenii. Примерно на } \\
\text { этом же уровне } \\
\text { появляются Achomo- } \\
\text { sphaera перtuni и S. } \\
\text { anthophorum. Верхняя } \\
\text { граница проводится по } \\
\text { появлению Gochteodinia } \\
\text { villosa, } \\
\text { ramosus. }\end{array}$ & $\begin{array}{l}\text { Достаточно многочисленны проксиматные (5-19\%) и хоратные (0.5-10\%) диноцисты плохой сохранности, а } \\
\text { также групп Escharisphaeridia-Batiacasphaera (0.5-24.5\%) и Sentusidinium-Barbatacysta (0.5-11\%). } \\
\text { Сокращается количество диноцист рода Dingodinium (0.5-20\%). Постоянно присутствуют Pareodinia spp., D. } \\
\text { jurassicum (1-3\%), D. albertii (0.5-2.5\%), Cribroperidinium granuligerum, C. sarjeantii (Vozzhennikova) Helenes, } \\
\text { Lithodinia arcanitabulata Brenner, Systematophora spp., Escharisphaeridia granulata (0.5-6\%), E. psilata (0.5- } \\
\text { 3\%), E. rudis Davies (0.5-5\%), E. dicrypta (0,5-3\%), E. rugosa (Courtinat) Courtinat, Pilosidinium microcystum } \\
\text { (Bujak) Courtinat, Barbatacysta pelionensis (Fensome) Courtinat (1-3.5\%), Tenua hystrix Eisenack, Circulodinium } \\
\text { compta (Davey) Helby, C. copei (0.5-5\%). Появляютя Kleithriasphaeridium corrugatum Davey, } \\
\text { Stiphrosphaeridium dictyophorum, S. anthophorum (Cookson et Eisenack) Lentin et Williams, Dingodinium } \\
\text { spinosum, Cribroperidinium hansenii, Achomosphaera neptuni (Eisenack) Davey et Williams, Oligosphaeridium } \\
\text { patulum Riding et Thomas. Продолжают встречаться акритархи pодов Solisphaeridium, Michrystridium, } \\
\text { Veryhahium. Среди празинофитов наибольшего количества достигает род Leiosphaeridia (3.5-18\%, иногда до } \\
\text { 84\%). В меньшем количестве определены Pterospermella (0-6.5\%), Cymatiosphaera (0-1.5\%), Tasmanites (0- } \\
\text { 5.5\%). }\end{array}$ \\
\hline $\begin{array}{l}\text { Зона Goch- } \\
\text { teodinia } \\
\text { villosa (ДК } \\
\text { Gr5); } \\
\text { мощность } \\
2.3 \text { м }\end{array}$ & $\begin{array}{l}\text { Нижняя проводится по } \\
\text { появлению Gochteodinia } \\
\text { villosa и Spiniferites } \\
\text { ramosus. Верхняя не } \\
\text { определена из-за пере- } \\
\text { рыва в осадконакоп- } \\
\text { лении. }\end{array}$ & $\begin{array}{l}\text { Достаточно многочисленны проксиматные (6.5-19\%) и хоратные (0.5-5.5\%) диноцисты плохой сохранности. } \\
\text { Сокращается количество диноцист рода Dingodinium (0.5-1.5\%), групп Escharisphaeridia-Batiacasphaera (9- } \\
\text { 15.5\%) и Sentusidinium-Barbatacysta (0.5-2\%). Большинство видов встречаются единично, но некоторые } \\
\text { (Escharisphaeridia rudis, E. dicrypta, E. pocockii) иногда присутствуют в небольшом количестве (до 5\%). } \\
\text { Характерно постоянное присутствие хоратных диноцист, представленных родами Kleithriasphaeridium, } \\
\text { Spiniferites, Oligosphaeridium, Systematophora, Stiphrosphaeridium, Perisseiasphaeridium, Tanyosphaeridium. } \\
\text { Хоратные диноцисты группы Cleistosphaeridium-Downiesphaeridium присутствуют в значительном } \\
\text { количестве (6-11\%). Наиболее многочисленны виды Impletosphaeridium lumectum (до 9\%) и I. polytrichum (до } \\
\text { 5\%). Появляются Gochteоdinia villosa, Spiniferites ramosus, Coronifera aff. oceanica, Cordosphaeridium inodes. } \\
\text { Среди проксиматных форм разнообразны роды Meiourogonyaulax, Leptodinium, Cribroperidinium и } \\
\text { Scriniodinium, однако разнообразие последних двух родов начинает сокращаться. Также сохраняется } \\
\text { разнообразие ареолигеровых диноцист. Резко сокращается разнообразие и количество (до 0.5-1\%) } \\
\text { празинофитов родов Cymatiosphaera, Pterospermella, Tasтапіtes и акритарх. Последние представлены только } \\
\text { Michrystridium fragile и Veryhachium spp. Количество празинофитов Leiosphaeridia также становится меньше } \\
\text { (6-9\%). }\end{array}$ \\
\hline $\begin{array}{l}\text { Слои с } \\
\text { Aptea } \\
\text { anaphrissa, } \\
\text { Gardodi- } \\
\text { nium } \\
\text { trabecu- } \\
\text { losum (ДК } \\
\text { Gr6); } \\
\text { мощность } \\
14.7 \text { м }\end{array}$ & 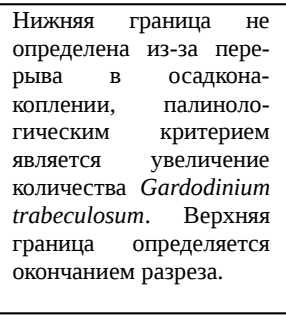 & $\begin{array}{l}\text { Разнообразие диноцист сокращается, особенно в верхней части слоев. В комплексе присутствуют } \\
\text { представители родов Batioladinium, Pareodinia, Trichodinium, Oligosphaeridinium и другие. Появляются } \\
\text { Batioladinium longicornutum, Microdinium ornatum, Pseudoceratium sp., Aptea anaphrissa. Часто встречаются } \\
\text { представители родов Microdinium, Apteodinium и группы Sentusidinium-Barbatacysta. Иногда значительного } \\
\text { количества достигают диноцисты родов Dingodinium (0.5-5.5\%), Sepispinula (0-7\%), Wallodinium (0-4.5\%), } \\
\text { группы Escharisphaeridia-Batiacasphaera (0.5-15\%), а также виды Gardodinium trabeculosum (0-16.5\%) и } \\
\text { Stephanelytron membranoideum (0-10\%). Среди акритарх в малом количестве (0.5-1\%) определены } \\
\text { Micrhystridium deflandrei, M. fragile, M. pyramidispinosum, Veryhachium? irregulare, Veryhahium formosum, V. } \\
\text { euporaeum, V. downiei. Обильны празинофиты рода Leiosphaeridia (16.5-71\%). В меньшем количестве } \\
\text { встречаются представители родов Pterospermella (1.5-22.5\%), Cymatiosphaera (0.5-2.5\%) и Tasmanites (0.5- } \\
\text { 3\%). }\end{array}$ \\
\hline
\end{tabular}


Табл. 1. Палинологическая характеристика биостратиграфических подразделений по диноцистам. 


\begin{tabular}{|c|c|c|}
\hline $\begin{array}{l}\text { Название } \\
\text { палино- } \\
\text { стратона, } \\
\text { мощность }\end{array}$ & Обоснование границ & Характерный комплекс \\
\hline $\begin{array}{l}\text { Слои с } \\
\text { Selaginella } \\
\text { granata (ПК } \\
\text { Gr1); } \\
\text { мощность } \\
14.1 \text { м. }\end{array}$ & $\begin{array}{l}\text { Нижняя не прослежена и определяется началом } \\
\text { разреза, верхняя определяется сокращением обилия } \\
\text { пыльцы Classopollis и увеличением количества спор } \\
\text { глейхениевых. }\end{array}$ & $\begin{array}{l}\text { Доминирует пыльца голосеменных растений (42-71\%). Oсобенно обильна } \\
\text { пыльца хейролепидиевых, представленная родом Classopollis (37-60\%). В } \\
\text { небольшом количестве присутствуют Ginkgocycadophytus spp. (2-6\%). } \\
\text { Характерно разнообразие мешковой пыльцы древних сосновых родов } \\
\text { Quadraequlina, Protopinus, Piceites, Pseudopicea и др. Вместе с тем, присутствует } \\
\text { пыльца сосновых, близкая к современным морфотипам (Piceapollenites, } \\
\text { Pinuspollenites). Среди спор главная роль принадлежит глейхениевым } \\
\text { папоротникам родов Gleicheniidites (4-15\%) и Plicifera (8-23\%). Среди них } \\
\text { присутствуют морфотипы с бугорчатой и шиповатой экзиной: Gleichenia } \\
\text { conspicienda Bolchovitina, G. parvipunctata, Ornamentifera echinata, O. granulata. } \\
\text { Споры циатейных/диптерисовых папоротников немногочисленны: Cyathidites } \\
\text { spp. (1-5\%), Concavisporites spp. (0.5-3.5\%) и др. Иногда встречаются споры } \\
\text { осмундовых и схизейных папоротников. Достаточно paзнообразны споры мхов и } \\
\text { плауновидных. Важно отметить присутствие вида Selaginella granata. }\end{array}$ \\
\hline $\begin{array}{l}\text { Слои с } \\
\text { Gleicheni- } \\
\text { idites tori- } \\
\text { concavus, } \\
\text { Plicatella } \\
\text { chetaensis } \\
\text { (ПК Gr2); } \\
\text { мощность } \\
10.5 \text { м. }\end{array}$ & $\begin{array}{l}\text { Нижняя граница проводится условно, так как } \\
\text { образцы из нижней части аммонитовой зоны } \\
\text { Dorsoplanites panderi плохо насыщены спорами и } \\
\text { пыльцой, а в интервале зон Ilowaiskya pseudoscythica } \\
\text { и I. sokolovi - отсутствуют. В основании слоев } \\
\text { появляется Gleicheniidites toriconcavus Krutzsch, } \\
\text { увеличивается количество спор глейхениевых в } \\
\text { целом и сокращается обилие пыльцы Classopollis. } \\
\text { Вблизи границы появляются споры схизейных с } \\
\text { бугорчатой и ребристой скульптурой родов } \\
\text { Concavissimisporites, Trilobosporites, Cicatricosi- } \\
\text { sporites и Plicatella, в составе которых определены } \\
\text { виды Cicatricosisporites sibiricus (Каra-Mursa) } \\
\text { Chlonova и Plicatella chetaensis (Каra-Mursa) } \\
\text { Воndarenko. Bepхняя граница тоже проводится } \\
\text { условно по последнему образцу из волжского } \\
\text { интервала, так как между волжским ярусом и } \\
\text { готеривом в разрезе Городищи наблюдается } \\
\text { перерыв. }\end{array}$ & $\begin{array}{l}\text { В комплексе доминируют споры (52-23\%). Среди них возрастает количество } \\
\text { спор глейхениевых папоротников (Gleicheniidites, 11-25.5\%; Plicifera, 6-34\%), } \\
\text { появляется вид Gleicheniidites toriconcavus. В составе схизейных папоротников } \\
\text { появляются морфотипы с бугорчатой и ребристой скульптурой родов } \\
\text { Concavissimisporites, Trilobosporites, Cicatricosisporites, Plicatella, } \\
\text { Contignisporites. Важно присутствие Cicatricosisporites sibiricus и Plicatella } \\
\text { chetaensis. В пыльцевой части комплекса сокращается количество Classopollis } \\
\text { spp. (12-34\%). Остальные характеристики комплекса меняются незначительно. }\end{array}$ \\
\hline $\begin{array}{l}\text { Слои с } \\
\text { Cicatricosi- } \\
\text { sporites } \\
\text { stoveri, } \\
\text { Gleicheni- } \\
\text { idites spp., } \\
\text { Pinuspol- } \\
\text { lenites spp. } \\
\text { (ПК Gr3); } \\
\text { мощность } \\
14.7 \text { м. }\end{array}$ & $\begin{array}{l}\text { Границы проводятся условно: нижняя - из-за } \\
\text { стратиграфического перерыва между волжским } \\
\text { ярусом и готеривом, верхняя определяется } \\
\text { окончание разреза и проводится по последнему } \\
\text { образцу. }\end{array}$ & $\begin{array}{l}\text { Резко доминируют споры (70-93.5\%). Наблюдается дальнейшее увеличение } \\
\text { количества спор глейхениевых папоротников (Gleicheniidites, 23-64\%; Plicifera, } \\
\text { 21-40.5\%; Ornamentifera, 1-6\%), появляются Ornamentifera peregrina, O. } \\
\text { tuberculata, Gleicheniidites radiatus и другие виды. Значительно возрастает } \\
\text { разнообразие ребристых спор схизейных папоротников родов Cicatricosisporites } \\
\text { и Plicatella, но их количество невелико (0-4\%). Важно отметить появление вида } \\
\text { Cicatricosisporites stoveri. В пыльцевой части комплекса резко сокращается } \\
\text { количество Classopollis spp. (1-5\%). Увеличивается доля мешковой пыльцы } \\
\text { хвойных, особенно Pinuspollenites spp. (2-13\%). В составе этой группы часто } \\
\text { встречается пыльца кедровых (Cedripites spp.). }\end{array}$ \\
\hline
\end{tabular}

Табл. 2. Палинологическая характеристика слоев со спорами и пыльцой. 


\begin{tabular}{|c|c|c|}
\hline $\begin{array}{c}\text { Диноцистовые } \\
\text { биостратоны }\end{array}$ & Биособытия & Биостратиграфическое и корреляционное значение биособытий \\
\hline \multirow[t]{3}{*}{$\begin{array}{l}\text { 3она Gonyaula- } \\
\text { cysta jurassica } \\
\text { subsp. jurassica }\end{array}$} & $\begin{array}{l}\text { Исчезновение вида-индекса в кровле } \\
\text { зоны }\end{array}$ & $\begin{array}{l}\text { Прослежено на том же уровне, что и по данным Riding et al., 1999. Ненадеж- } \\
\text { ный корреляционный признак, так как вид может встречаться в средней и } \\
\text { верхней частях волжского яруса на севере Западной Европы [Heilmann- } \\
\text { Clausen, 1987; Poulsen, Riding, 2003], в середине берриаса на севере Сибири } \\
\text { [Пещевицкая, 2010]. }\end{array}$ \\
\hline & $\begin{array}{l}\text { Исчезновение Cribroperidinium ehren- } \\
\text { bergii, С.? "саuda", C.? "systremmatos", } \\
\text { в верхней части зоны }\end{array}$ & $\begin{array}{l}\text { Не прослеживаются выше кимериджа в Англии и Франции [Gitmez, Sarjeant, } \\
\text { 1972]. }\end{array}$ \\
\hline & $\begin{array}{l}\text { Появление Exоchosphaeridium phragmites } \\
\text { в верхней части зоны }\end{array}$ & $\begin{array}{l}\text { Наиболее древние находки этого вида, характерен для берриаса-готерива За- } \\
\text { падной Европы [Davey, 1982; Leereveld, 1997]. }\end{array}$ \\
\hline \multirow[t]{3}{*}{$\begin{array}{l}\text { 3она Corculodini- } \\
\text { um inaffectum }\end{array}$} & $\begin{array}{l}\text { Появление Cribroperidinium? edwardsii } \\
\text { в основании зоны }\end{array}$ & $\begin{array}{l}\text { Корреляция с верхним кимериджем Сибири (верхи аммонитовой зоны Amoе- } \\
\text { boceras elegans) [Никитенко и др., 2015]. }\end{array}$ \\
\hline & $\begin{array}{l}\text { Исчезновение вида-индекса в кровле } \\
\text { зоны }\end{array}$ & $\begin{array}{l}\text { По материалам автора на этом уровне прекращаются постоянные находки } \\
\text { вида, но исчезает он в средневолжском подъярусе. Ha севере Западной Ев- } \\
\text { ропы может встречаться в рязанском ярусе [Heilmann-Clausen, 1987]. }\end{array}$ \\
\hline & $\begin{array}{l}\text { Появление Cometodinium whitei в низах } \\
\text { зоны }\end{array}$ & $\begin{array}{l}\text { Появляется в переходном кимериддж-титонском интервале уровне в Багамс- } \\
\text { ком бассейне [Habib, Drugg, 1983; Zotto et al., 1987]. }\end{array}$ \\
\hline \multirow[t]{3}{*}{$\begin{array}{l}\text { Слои с Muderongia } \\
\text { simplex }\end{array}$} & $\begin{array}{l}\text { Появление вида-индекса в основании } \\
\text { слоев }\end{array}$ & $\begin{array}{l}\text { Корреляция с севером Западной Европы (аммонитовые зоны Pectinatites pec- } \\
\text { tinatus - Pavlovia pallasioides) [Poulsen, Riding, 2003]. }\end{array}$ \\
\hline & $\begin{array}{l}\text { Исчезновение Cribroperidinium crassi- } \\
\text { nervum в основании слоев }\end{array}$ & $\begin{array}{l}\text { Корреляция с севером Западной Европы, аммонитовая зона Pavlovia pallasioi- } \\
\text { des [Nohr-Hansen, 1986]. }\end{array}$ \\
\hline & $\begin{array}{l}\text { Исчезновение Meiourogonyaulax bejui } \\
\text { в основании слоев }\end{array}$ & $\begin{array}{l}\text { Корреляция с Болгарией, основание среднего титона [Dodekova, 1994] и Да- } \\
\text { нией, аммонитовая зона Pectinatites pectinatus [Poulsen, 1996]. }\end{array}$ \\
\hline \multirow{8}{*}{$\begin{array}{l}\text { Слои с Achomo- } \\
\text { sphaera neptunii, } \\
\text { Cribroperidinium } \\
\text { hansenii }\end{array}$} & $\begin{array}{l}\text { Появление Achomosphaera neptunii в } \\
\text { основании слоев }\end{array}$ & $\begin{array}{l}\text { Корреляция с Данией, вид появляется в средней части средневолжского } \\
\text { подъяруса [Heilmann-Clausen, 1987]. }\end{array}$ \\
\hline & $\begin{array}{l}\text { Появление Cribroperidinium hansenii в } \\
\text { основании слоев }\end{array}$ & $\begin{array}{l}\text { Корреляция с Данией, вид появляется на уровне аммонитовой зоны Progal- } \\
\text { banite albani [Poulsen, 1996]. }\end{array}$ \\
\hline & $\begin{array}{l}\text { Появление Stiphrosphaeridium dictyopho- } \\
\text { rum, S. anthophorum в основании слоев }\end{array}$ & $\begin{array}{l}\text { Наиболее древние находки, в Норвегии виды появляются в верхней части } \\
\text { средневолжского - низах верхневолжского подъярусов [Dybkjaer, 1998]. }\end{array}$ \\
\hline & $\begin{array}{l}\text { Появление Dingodinium spinosum в осно- } \\
\text { вании слоев }\end{array}$ & $\begin{array}{l}\text { Наиболее древние находки этого вида. На севере Западной Европы рассмат- } \\
\text { ривается как важный биостратиграфический маркер, но появляется там выше, } \\
\text { на уровне, соответствующем средней-верхней части средневолжского подъя- } \\
\text { руса (аммонитовая зона Galbanite okusensis) [Poulsen, Riding, 2003]. }\end{array}$ \\
\hline & $\begin{array}{l}\text { Исчезновение Glossodinium dimorphum в } \\
\text { верхней части аммонитовой зоны Dorso- } \\
\text { planites panderi }\end{array}$ & $\begin{array}{l}\text { На севере Западной Европы исчезает на уровне средней-верхней части аммо- } \\
\text { нитовой зоны Epivirgatites nikitinii (зона Titanites anguiformis) [Poulsen, Riding, } \\
\text { 2003]. }\end{array}$ \\
\hline & $\begin{array}{l}\text { Появление Kleithriasphaeridium corrugatum } \\
\text { в верхней части аммонитовой зоны Dorso- } \\
\text { planites panderi }\end{array}$ & $\begin{array}{l}\text { Наиболее древние находки этого вида. На севере Западной Европы появля- } \\
\text { ется на уровне аммонитовой зоны Galbanite okusensis [Powell, 1992]. }\end{array}$ \\
\hline & $\begin{array}{l}\text { Появление Oligosphaeridium patulum в } \\
\text { верхней части аммонитовой зоны Dorso- } \\
\text { planites panderi }\end{array}$ & $\begin{array}{l}\text { В Сибири этот вид появляется в нижней части средневолжского подъяруса } \\
\text { [llyina et al., 2005], но на севере Западной Европы - значительно раньше, с ки- } \\
\text { мериджа (аммонитовая зона Rasenia суmodoce) [Powell, 1992]. }\end{array}$ \\
\hline & $\begin{array}{l}\text { Исчезновение Оссіsucysta balios в } \\
\text { кровле аммонитовой зоны Dorsoplani- } \\
\text { tes panderi }\end{array}$ & $\begin{array}{l}\text { Корреляция с севером Западной Европы, аммонитовые зоны Virgatopavlovia } \\
\text { fittoni - Protogalbanites albani [Poulsen, 1996; Poulsen, Riding, 2003]. }\end{array}$ \\
\hline \multirow[t]{4}{*}{$\begin{array}{l}\text { 3она Gochteodi- } \\
\text { nia villosa }\end{array}$} & $\begin{array}{l}\text { Появление вида-индекса в основании } \\
\text { зоны }\end{array}$ & $\begin{array}{l}\text { Корреляция с севером Западной Европы, где появление вида на уровне ам- } \\
\text { монитовой зоны Kerberites kerberus рассматривается как важный стратиграф- } \\
\text { ический и корреляционный peпер [Davey, 1982; Heilmann-Clausen, 1987; Po- } \\
\text { well, 1992; Poulsen, 1996; Poulsen, Riding, 2003]. }\end{array}$ \\
\hline & $\begin{array}{l}\text { Появление представителей рода Spini- } \\
\text { ferites в основании зоны }\end{array}$ & $\begin{array}{l}\text { Корреляция с Болгарией (Spiniferites alatus появляется в основании верхнего } \\
\text { титона) [Dodekova, 1994] и Данией (Spiniferites ramosus появляется в переход- } \\
\text { ных средне-верхневолжских слоях) [Heilmann-Clausen, 1987]. }\end{array}$ \\
\hline & $\begin{array}{l}\text { Исчезновение Epiplosphaera reticulo- } \\
\text { spinosa в нижней части аммонитовой } \\
\text { зоны Kachpurites fulgens }\end{array}$ & $\begin{array}{l}\text { Корреляция с Болгарией, вид исчезает в кровле среднего титона [Dodekova, } \\
\text { 1994]. }\end{array}$ \\
\hline & $\begin{array}{l}\text { Исчезновение Oligosphaeridium patu- } \\
\text { lum в нижней части аммонитовой зоны } \\
\text { Kachpurites fulgens }\end{array}$ & $\begin{array}{l}\text { Корреляция с Сибирью, вид исчезает в кровле средневолжского подъяруса } \\
\text { [llyina et al., 2005]. }\end{array}$ \\
\hline \multirow[t]{2}{*}{$\begin{array}{l}\text { Слои с Aptea } \\
\text { anaphrissa, Gar- } \\
\text { dodinium trabe- } \\
\text { culosum }\end{array}$} & Акме Gardodinium trabeculosum & $\begin{array}{l}\text { Корреляция с Приполярным Уралом (аммонитовая зона Speetoniceras versico- } \\
\text { lor) [Лебедева, Никитенко, 1998] и севером Западной Европы - акме, где уве- } \\
\text { личение этого вида рассматривается как важный биостратиграфический и } \\
\text { корреляционный признак (аммонитовая зона Endemoceras regale [Davey, 1979; } \\
\text { Rawson, Riley, 1982]. }\end{array}$ \\
\hline & Появление Aptea anaphrissa & $\begin{array}{l}\text { Корреляция с Сибирью и Приполярным Уралом (интервал аммонитовой зоны } \\
\text { Speetoniceras versicolor) [Лебедева, Никитенко, 1998; Пещевицкая, 2010; Ни- } \\
\text { китенко и др., 2013], Баренцевоморским шельфом (интревал аммонитовых } \\
\text { зон Endemoceras regale - Speetoniceras inversum) [Smelror et al., 1998], а так- } \\
\text { же Норвегией, Данией и Арктической Канадой (средняя часть готерива) [Ро- } \\
\text { cock, 1976; Aarhus et al., 1986; Heilmann-Clausen, 1987]. }\end{array}$ \\
\hline
\end{tabular}




\begin{tabular}{|c|c|c|}
\hline \begin{tabular}{|} 
Диноцистовые \\
биостратоны
\end{tabular} & Биособытия & Биостратиграфическое и корреляционное значение биособытий \\
\hline \multirow[t]{10}{*}{$\begin{array}{l}\text { 3она Glossodinium } \\
\text { dimorphum }\end{array}$} & $\begin{array}{l}\text { Появление Amphorulacysta expirata в ce- } \\
\text { редине аммонитовой зоны Dorzoplanites } \\
\text { panderi }\end{array}$ & $\begin{array}{l}\text { Наиболее древние находки на территории Англии в интервале, соответству- } \\
\text { ющем верней части нижневолжского подъяруса, Дорсет, аммонитовая зона } \\
\text { Pectinatites hudlestoni [Riding, Thomas, 1988]. На севере Германии присутству- } \\
\text { ет в оксфорде [Kuntz, 1990]. }\end{array}$ \\
\hline & $\begin{array}{l}\text { Появление Rhynchodiniopsis martonense в } \\
\text { cередине аммонитовой зоны Dorzoplanites } \\
\text { panderi }\end{array}$ & $\begin{array}{l}\text { Появляется на территории Англии в интервале, соответствующем верней час- } \\
\text { ти нижневолжского подъяруса, аммонитовая зона Pectinatites hudlestoni [Bailey } \\
\text { et al., 1997]. }\end{array}$ \\
\hline & $\begin{array}{l}\text { Появление Avellodinium falcificum в cepe- } \\
\text { дине аммонитовой зоны Dorzoplanites } \\
\text { panderi }\end{array}$ & $\begin{array}{l}\text { Наиболее древние находки вида, ранее его появление фиксировалось в вер- } \\
\text { хнем портланде на севере Западной Европы [Davey, 1982]. }\end{array}$ \\
\hline & $\begin{array}{l}\text { Появление Egmontodinium toryna в cepe- } \\
\text { дине аммонитовой зоны Dorzoplanites } \\
\text { panderi }\end{array}$ & $\begin{array}{l}\text { Появляется на территории Англии и Северного моря в верхней части киме- } \\
\text { риджа, аммонитовая зона Aulacostephanus autissiodorensis [Powell, 1992]. }\end{array}$ \\
\hline & $\begin{array}{l}\text { Появление Scriniodinium intribile в cepe- } \\
\text { дине аммонитовой зоны Dorzplanites pan- } \\
\text { deri }\end{array}$ & $\begin{array}{l}\text { Появляется на территории Англии и Северного моря в середине оксфорда } \\
\text { [Рowell, 1992]. }\end{array}$ \\
\hline & \begin{tabular}{|l|} 
Появление Scriniodinium pharo в середине \\
аммонитовой зоны Dorzoplanites panderi
\end{tabular} & $\begin{array}{l}\text { Появляется на территории Англии и Северного моря в основании портланда } \\
\text { [Powell, 1992], но в Польше - с верхов кимериджа, аммонитовая зона Aulaco- } \\
\text { stephanus autissiodorensis [Poulsen, 1993]. }\end{array}$ \\
\hline & $\begin{array}{l}\text { Исчезновение Cribroperidinium erymnosep- } \\
\text { tatum в cередине аммонитовой зоны Dor- } \\
\text { zoplanites panderi }\end{array}$ & По новым данным исчезает верхневолжском подъярусе (рис. 2). \\
\hline & $\begin{array}{l}\text { Исчезновение Glossodinium dimorphum в } \\
\text { верхней части аммонитовой зоны Dorzo- } \\
\text { planites panderi }\end{array}$ & $\begin{array}{l}\text { Исчезает на территории Англии и Северного моря в интервале, соответству- } \\
\text { ющем верхнеи части средневолжского подъяруса, аммонитовая зона Titanites } \\
\text { anguiformis [Powel, 1992]. }\end{array}$ \\
\hline & $\begin{array}{l}\text { Появление Senoniasphaera jurassica в вер- } \\
\text { хней части аммонитовой зоны Dorzoplani- } \\
\text { tes panderi }\end{array}$ & $\begin{array}{l}\text { Появляется на севере Западной Европы в основании кимериджа, аммонито- } \\
\text { вая зона Pictonia bailey [Sarjeant, 1979], во Франции и Сибири - с верхнего } \\
\text { оксфорда [Fauconnier, 1995; Никитенко и др., 2015]. }\end{array}$ \\
\hline & \begin{tabular}{|l|} 
Появление Kleithriasphaeridium corrugatum \\
в верхней части слоев
\end{tabular} & $\begin{array}{l}\text { Наиболее древние находки этого вида. На севере Западной Европы появля- } \\
\text { ется на уровне аммонитовой зоны Galbanite okusensis [Powell, 1992]. }\end{array}$ \\
\hline \multirow[t]{7}{*}{$\begin{array}{l}\text { Зона Perisseias- } \\
\text { phaeridium inge- } \\
\text { gerdia }\end{array}$} & $\begin{array}{l}\text { Появление вида-индекса в нижней части } \\
\text { аммонитовой зоны Virgatites virgatus }\end{array}$ & $\begin{array}{l}\text { Появляется в Англии и Дании в верхнем кимеридже (аммонитовая зона Aula- } \\
\text { costephanus mutabilis) [Nohr-Hansen, 1986; Poulsen, 1996], в Польше - в ниж- } \\
\text { нем кимеридже (зона Ataxioceras hypselocyclum) [Poulsen, 1996]. }\end{array}$ \\
\hline & $\begin{array}{l}\text { Появление Isthmocystis distincta в нижней } \\
\text { части аммонитовой зоны Virgatites virgatus }\end{array}$ & $\begin{array}{l}\text { Наиболее древние находки этого вида. На севере Западной Европы появля- } \\
\text { ется на уровне аммонитовой зоны Galbanite kerberus [Powell, 1992]. }\end{array}$ \\
\hline & $\begin{array}{l}\text { Появление Egmontodinium polyplacopho- } \\
\text { rum в нижней части аммонитовой зоны } \\
\text { Virgatites virgatus }\end{array}$ & $\begin{array}{l}\text { Появляется на территории Англии и Северного моря на уровне, соответству- } \\
\text { ющем нижней части нижневолжского подъяруса, аммонитовая зона } \\
\text { Pectinatites elegans [Poulsen, Riding, 2003]. }\end{array}$ \\
\hline & $\begin{array}{l}\text { Появление Achomosphaera neptunii в ниж- } \\
\text { ней части аммонитовой зоны Virgatites vir- } \\
\text { gatus }\end{array}$ & $\begin{array}{l}\text { По новым данным появляется в верхней части аммонитовой зоны Dorsoplani- } \\
\text { tes pnaderi (рис. 2). }\end{array}$ \\
\hline & $\begin{array}{l}\text { Появление Kleithriasphaeridium eoinodes } \\
\text { в нижней части аммонитовой зоны Virgati- } \\
\text { tes virgatus }\end{array}$ & $\begin{array}{l}\text { Наиболее древние находки этого вида. На на территории Англии и Северного } \\
\text { моря появляется в берриасе [Duxbury, 1977; Heilmann-Clausen, 1987]. }\end{array}$ \\
\hline & \begin{tabular}{|l|} 
Появление Rhynchodiniopsis martonense в \\
в нижней части аммонитовой зоны Virgati- \\
tes virgatus
\end{tabular} & Наиболее молодые находки этого вида. \\
\hline & $\begin{array}{l}\text { Появление Kleithriasphaeridium porosispi- } \\
\text { num в средней части аммонитовой зоны } \\
\text { Virgatites virgatus }\end{array}$ & $\begin{array}{l}\text { Появляется на севере Западной Европы на уровне, соответствующе верхней } \\
\text { части нижневолжского подъяруса [Роwеll, 1992],наиболее древние находки } \\
\text { зафиксированы в Дании в аммонитовой зоне Pectinatites hudlestoni [Poulsen, } \\
\text { 1996]. }\end{array}$ \\
\hline \multirow[t]{6}{*}{$\begin{array}{l}\text { Зона Gochteodi- } \\
\text { nia villosa }\end{array}$} & $\begin{array}{l}\text { Появление вида-индекса в основании } \\
\text { зоны }\end{array}$ & $\begin{array}{l}\text { Корреляция с севером Западной Европы, где появление вида на уровне ам- } \\
\text { монитовой зоны Kerberites kerberus рассматривается как важный стратигра- } \\
\text { фический и корреляционный peпер [Davey, 1982; Heilmann-Clausen, 1987; Po- } \\
\text { well, 1992; Poulsen, 1996; Poulsen, Riding, 2003]. }\end{array}$ \\
\hline & $\begin{array}{l}\text { Исчезновение Scriniodinium intribile в } \\
\text { средней части аммонитовой зоны Касhрu- } \\
\text { rites fulgens }\end{array}$ & $\begin{array}{l}\text { Исчезает в середине берриаса на Баренцевоморском шельфе [Smelror, Dyp- } \\
\text { vik, 2005] и в Сибири (разрез Нордвик, материалы автора). }\end{array}$ \\
\hline & $\begin{array}{l}\text { Исчезновение Egmontodinium polyplaco- } \\
\text { phorum в верхней части аммонитовой зо- } \\
\text { ны Kachpurites fulgens }\end{array}$ & $\begin{array}{l}\text { Исчезает в средней части берриаса на севере Западной Европы [Aarhus et al., } \\
\text { 1986]. }\end{array}$ \\
\hline & $\begin{array}{l}\text { Появление Circulodinium compta в сред- } \\
\text { ней части аммонитовой зоны Craspedites } \\
\text { subditus }\end{array}$ & Появляется в верхнем оксфорде в Сибири [Никитенко и др, 2015]. \\
\hline & \begin{tabular}{l|} 
Исчезновение Senoniasphaera jurassica в \\
интервале аммонитовой зоны Craspedites \\
nodiger
\end{tabular} & $\begin{array}{l}\text { Таксон широкого стратиграфического распространения, верхний оксфорд - го- } \\
\text { терив [ Fauconnier, 1995; losifova, 1996; Никитенко и др, 2015]. }\end{array}$ \\
\hline & $\begin{array}{l}\text { Исчезновение Leptodinium subtile в интер- } \\
\text { вале аммонитовой зоны Craspedites nodi- } \\
\text { ger }\end{array}$ & $\begin{array}{l}\text { Исчезает в середине берриаса на Баренцевоморском шельфе [Aarhus et al., } \\
\text { 1986; Smelror et al., 1998]. }\end{array}$ \\
\hline
\end{tabular}




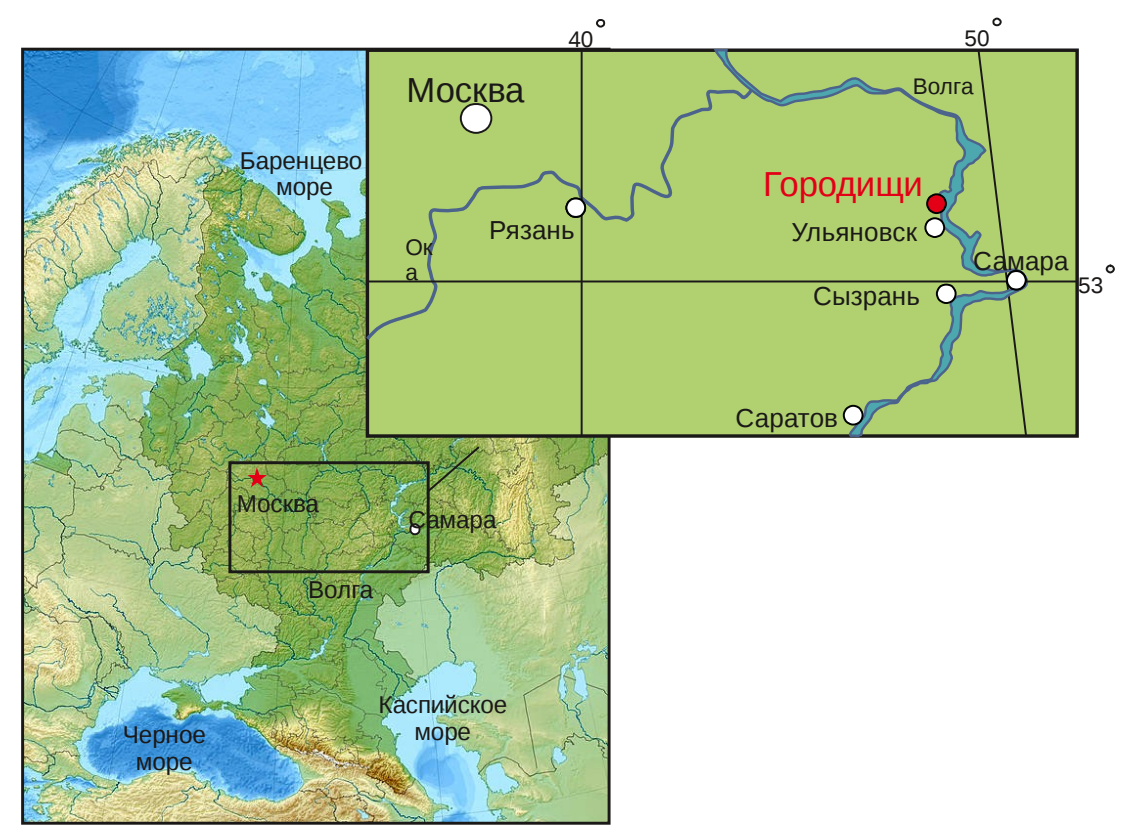




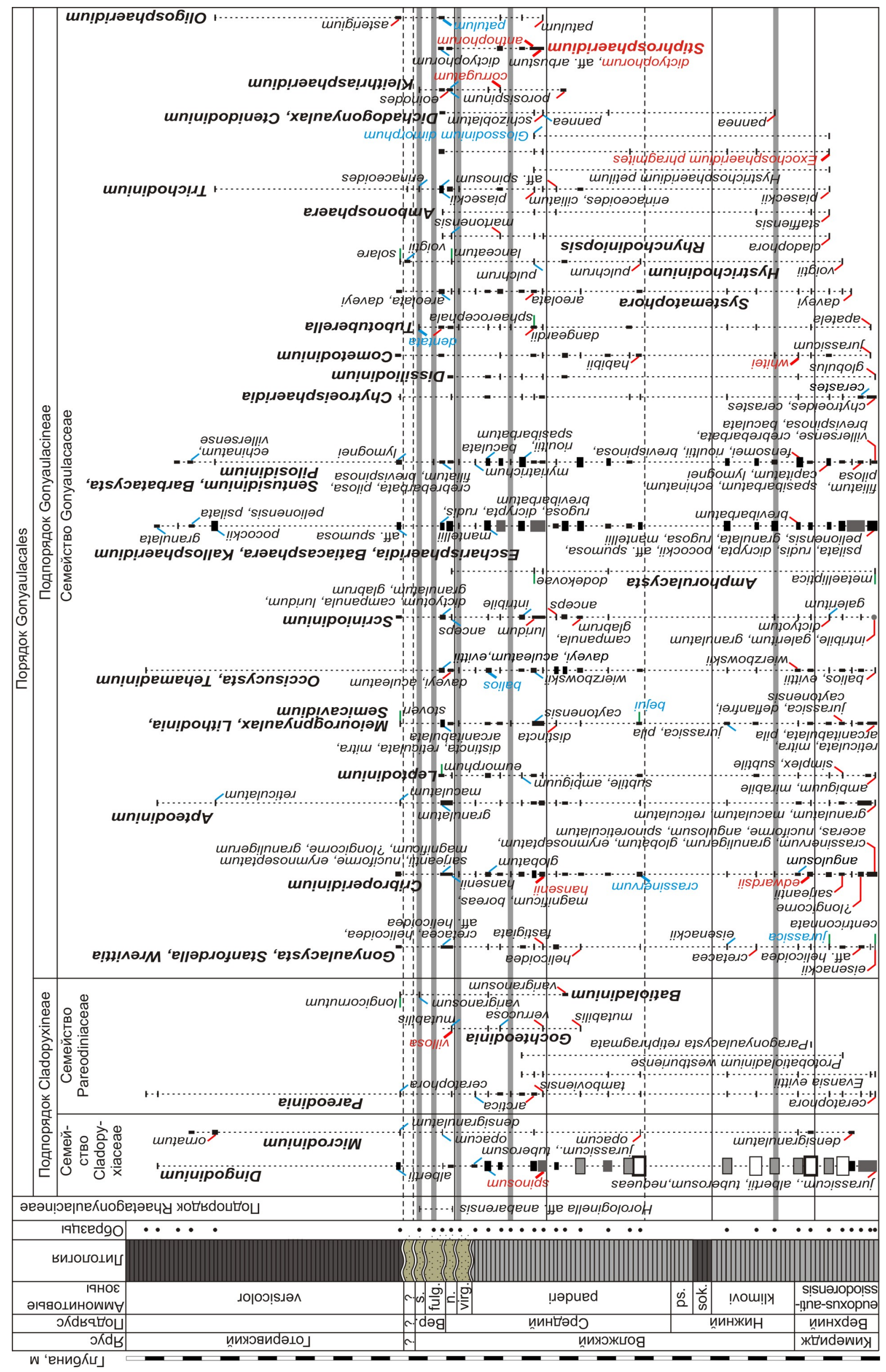




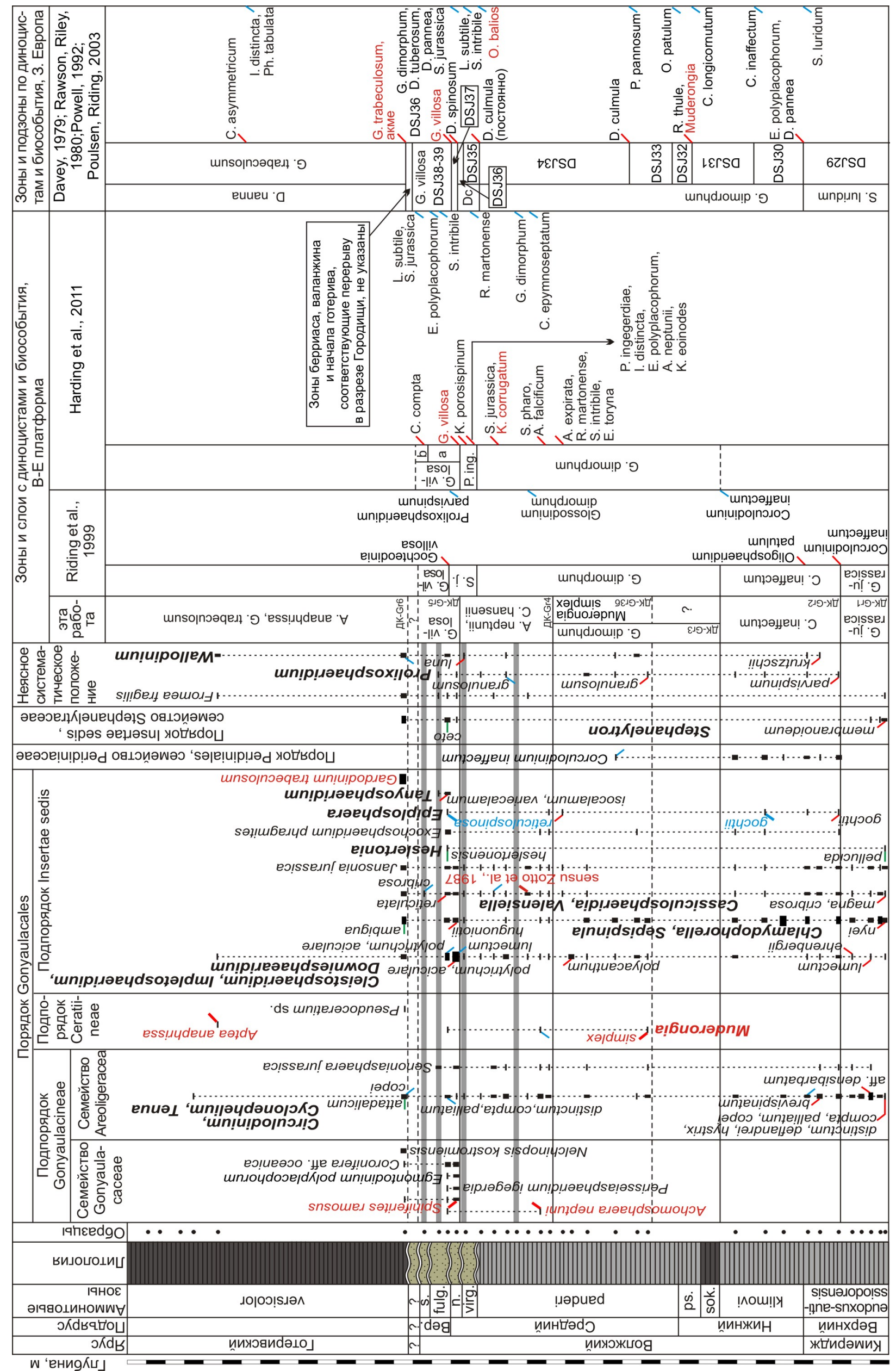



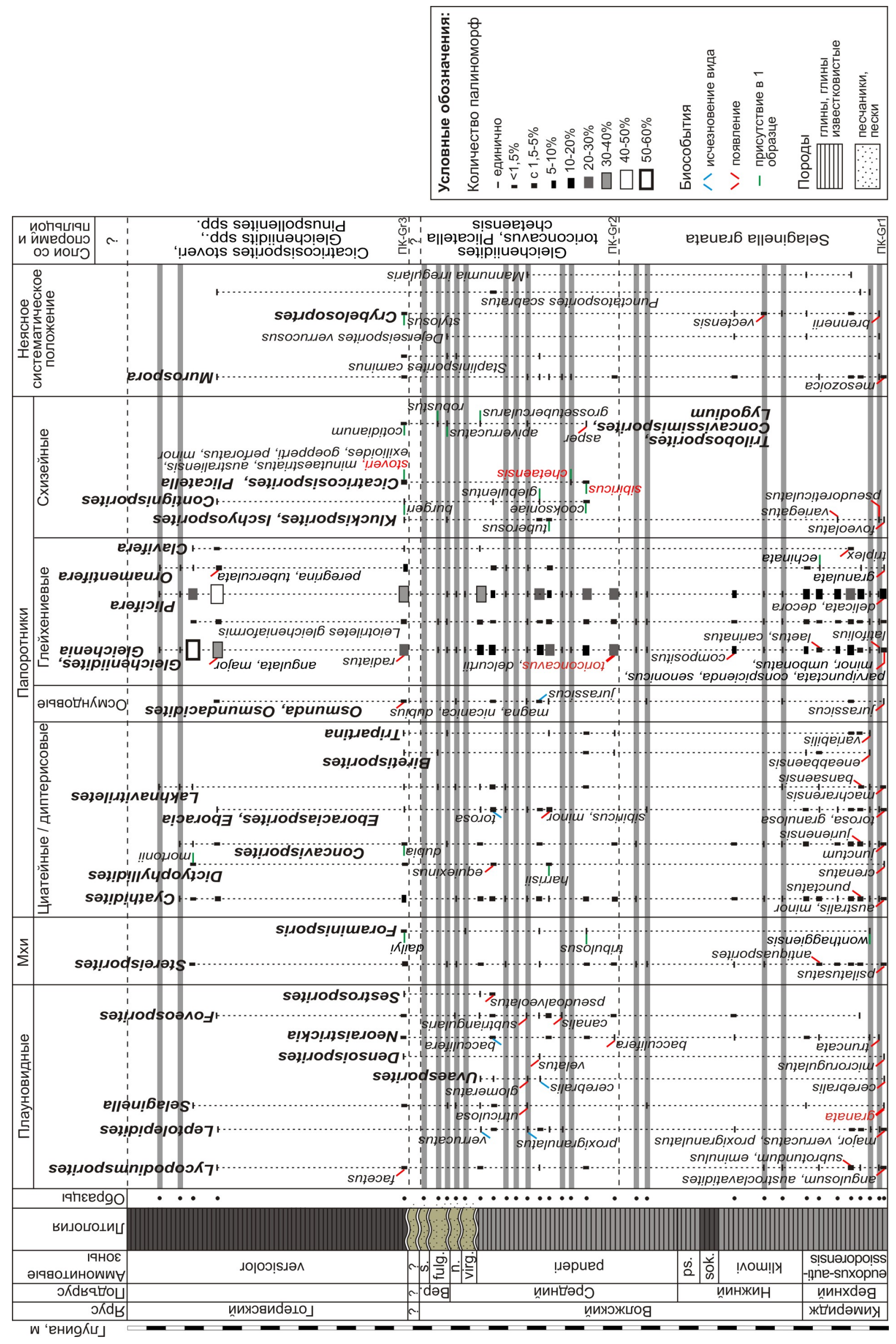


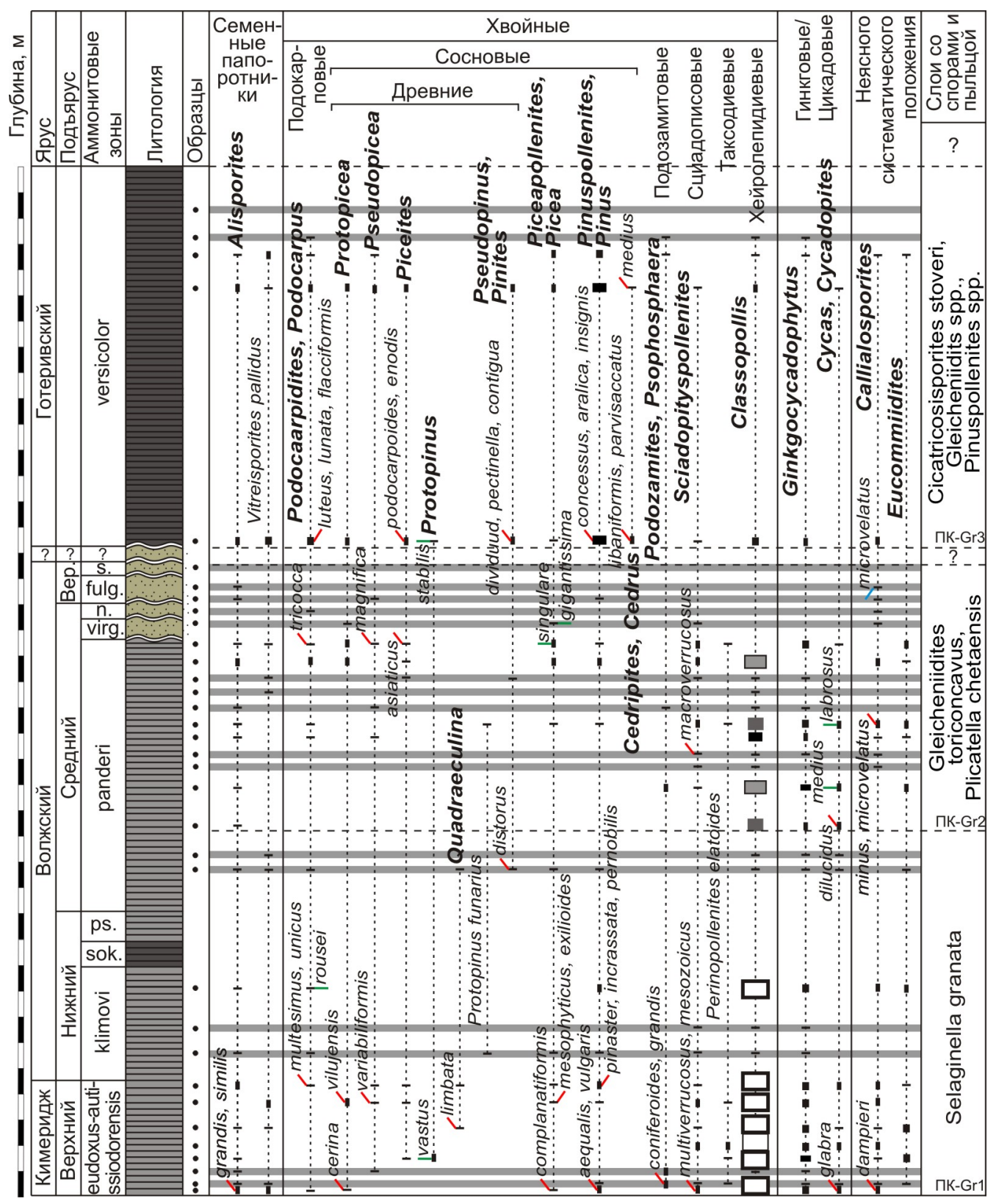




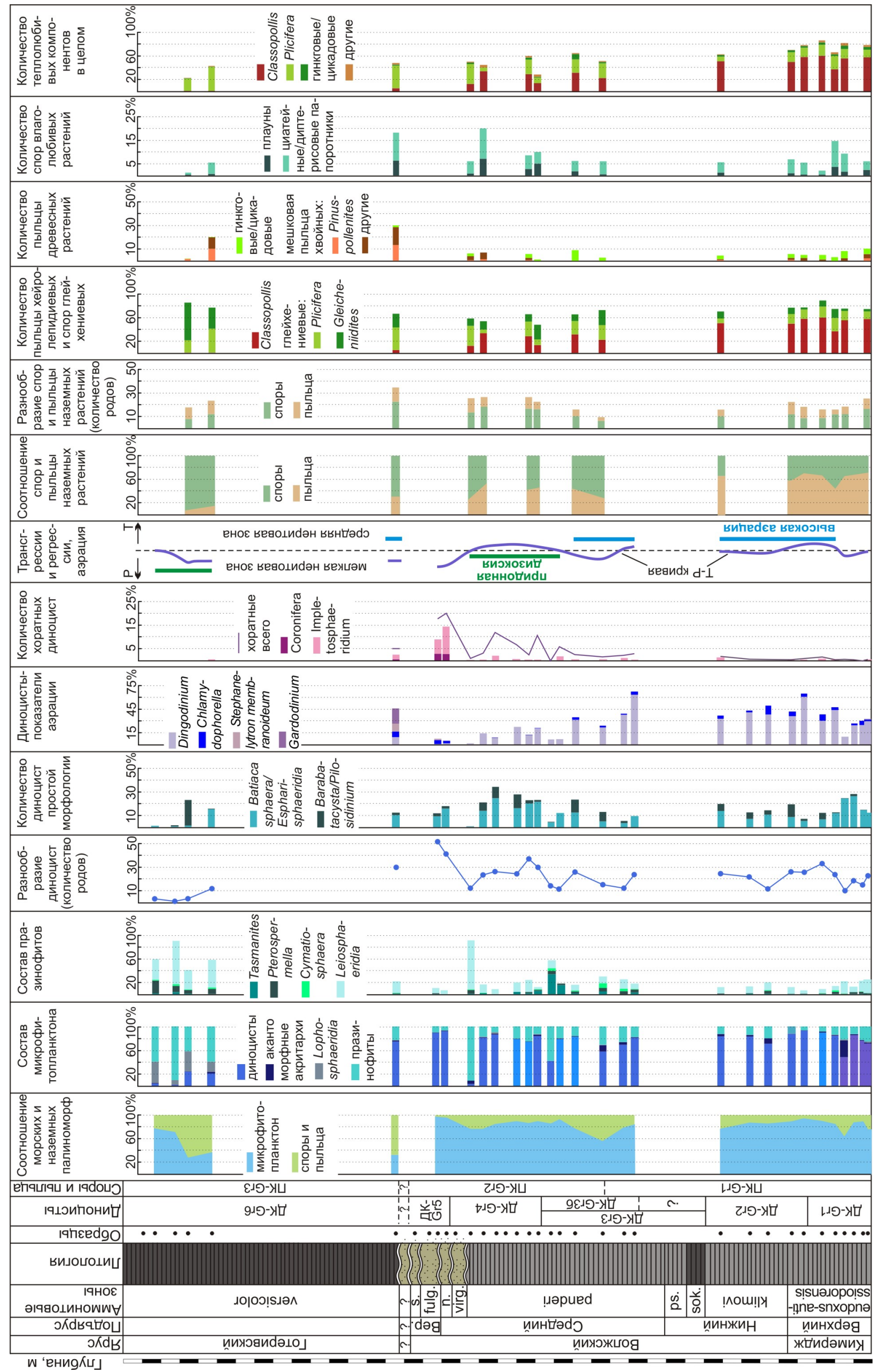

